\section{TOPONYMS IN THE WESTERN REGION OF THAILAND}

\section{Sujaritlak Deepadung ${ }^{1}$}

\begin{abstract}
Village names or toponyms in the Western region of Thailand, i.e. Kanchanaburi, Nakorn Pathom, Ratchaburi, Phetchaburi, Prachuap Khiri Khan, Samut Songkhram, Samut Sakorn and Suphan Buri, in this study are drawn from a complete list of names in Thamniap Thongthii 2535 $B C$ (Provincial Records 1992). The aims of this study are: 1) to analyse the linguistic structure of Thai village names 2) to set up dimensions for the semantic features of the village names in the western region of Thailand and 3) to make a frequency count of the general names which are the first morpheme of a name. The result are as follows: 1) the linguistic structure of the village names is the same as that of the grammatical word structure in Thai 2) there are five major semantic dimensions of the village names, namely, the geographical features which include water or sources of water, elevated land areas and other geographical areas, the nongeographical features which consist of plants, animals, uncultivated or the cultivated land and profession, constructed objects, numbers, persons, and other ethic languages, the locative or directional features which are divided into prepositional locatives and noun locatives, the auspicious features and the descriptive features,

1 Associate Professor, Institute of Language and Culture for Rural Development, Mahidol University, Thailand
\end{abstract}

and 3) the village names to the western region of Thailand rely significantly on physical geography of the area.

\section{Introduction}

The study of toponyms has attracted the interest of scholars such as linguists, anthropologists, etc. because toponymy or place names involves language, culture, history, geography, ways of living, in other words a great deal of knowledge about language and ethnic history of the geographical area in which they occur can be obtained from the study.

The author's interest in studying toponyms first came as the byproduct from one of the field trips for the "Field Methods in Linguistics" course; in looking at various villagename signs along the roads in Kanchanaburi province; I began to wonder how come I did not know the meanings of the village names. And it became an attempt in trying to know the place and the people since Mahidol University's new campus is in Kanchanaburi province. The study of toponyms is the answer. ${ }^{2}$ Later the study was enlarged to include the other seven provinces in the western region of Thailand.

\section{The New Encyclopedia Britannica (1992:849) defined 'toponymy' as follows:}

Toponymy, taxonomic study of place-names, based on etymological, historical, and geographical information. A

2 This paper was presented at the $8^{\text {th }}$ International Conference on Thai Studies, Ramkhamhaeng University, NakhonPhanom, Thailand, January 8-12, 2002 
place-name is a word or words used to indicate, denote, or identify a geographic locality such as a town, river, or mountain... Toponymy is concerned with the linguistic evolution (etymology) of placenames and the motive behind the naming of the place (historical and geographical aspects). Habitation and feature names are either generic or specific, or a combination of the two. A generic name refers to a class of names such as river, mountain, or town. A specific name serves to restrict or modify the meaning of the place-name.

That is, its evolution involves two things: word formations and geographical aspects. The present study is motivated even more by Franz Boas' statement that 'geographical terminology does not depend solely upon cultural interests but is also influenced by linguistic structure' (Boas, 1964:171). Up to the present time, there has been no study of toponyms in Thailand, specifically those concerning the village names of the western region of Thailand ${ }^{3}$. Thus, in this study the 4,916 village names of the eight provinces in the western region (see map 1), Kanchanaburi, Nakhon Pathom, Ratchaburi, Phetchaburi, Prachuap Khiri Khan, Samut Sakhon, Samut Songkhram and Suphanburi are classified and

${ }^{3}$ There was one study done by Jerry W. ainey on eastern and southern Thailand in 1984, which has given a lot of useful guidance for this study. The other study was conducted by Pranee Kullavanijya on the village names in Quangxi Province and the Northeastern Part of Thailand in 1992. This study on the Western region of Thailand was funded by Mahidol University. analyzed according to their linguistic structure and the motivation for that structure. The study has investigated the following aspects of Thai villages names: 1) the linguistic structure of the names; 2) the cultural and geographical dimensions of village names; and 3) the relationships of village names to the physical geography of the area.

\section{The Data}

The village names studied below are drawn from a complete list of names in Tham-niap thong-thii $2535 \mathrm{BC}$ (2535, Provincial Records 1992). ${ }^{4}$ Tham-niap thong-thii $2535 B C$ listed the numbers and names of all the provinces in Thailand. For the eight provinces in this study, the number of villages in each province is as follows:

1. Kanchanaburi $\quad 761$ villages (mùu bâan) (Tham niap 1992:55-74)

2. Nakhon Pathom 850 villages (mùu bâan )(Tham niap 1992:345- 361)

3. Ratchaburi 886 villages (mùu bâan) (Tham niap 1992:901-906)

4. Phetchaburi 630 villages (mùu bâan) (Tham niap 1992:737-750)

5. Prachuap Khiri Khan 354 villages (mùu bâan) (Tham niap 1992:591-600)

6. Samut Sakhon 293 villages (mùu bâan) (Tham niap 1992:1090-1096)

7. Samut Songkhram 278 villages (mùu bâan) (Tham niap 1992:1083- 1089) 8. Suphanburi 864 villages (mùu bâan) (Tham niap 1992:1140-1158) Total $\quad 4,916$ villages All the village names of the eight provinces from Tham-niap thong-thii $2535 B C$ were entered manually on

${ }^{4}$ This is the 1992 edition, the latest is the 1998 edition. This study began before the latest edition came out. 
cards. One card is for one village name together with a coding system of letters and numbers, representing provinces, districts, and sub-districts (See Appendix I). Then, the data were classified and counted, again manually, on the basis of the meaning of the first morpheme of the village names, so it is really a very slow process of classification, rearrangement counting and recounting. 5

\section{Geographical features of Western Thailand}

\begin{abstract}
According to Thai Cultural Landscape (1996:259), the western region of Thailand includes the provinces of Tak, Kanchanaburi, Ratchaburi, Phetchaburi and Prachuap Khiri Khan. The physical features of the region mostly include mountains and valleys, and some areas are close to the sea. The Central Thanon Thongchai Range starts in the north, passes through Tak province, and ends at the east side of the Kwai Noi River in Kanchanaburi. The Tenassarim Range starts out at the north of the Three Pagoda Pass in Sangkhlaburi district of Kanchanaburi and passes through Ratchaburi, Phetchaburi and Prachuap Khiri Khan and ends in Ranong province. Big alluvial plains are found in the western region, i.e., the Mae Klong alluvial plain along the Mae Klong River in Kanchanaburi,
\end{abstract}

${ }^{5}$ Collation of the data is done manually so that all the village names will be studied and analyzed along the way. A computerized database is compiled after the studied is done in order to show the distribution of the villages and the physical geography of the area, and to make use of all the facilities available from the Mahidol Ethnolinguistic Map Project
Ratchaburi and Samut Songkhram, and the coastal plains along the coastline of the western region start in Phetchaburi and ends in Prachuap Khiri Khan.

The four provinces in this study are located physically in the western region. The other four, namely, Nakhon Pathom, Suphanburi, Samut Sakhon and Samut Songkhram are geographically located in the central region of Thailand. ${ }^{6}$ Nakhon Pathom is where the main campus of Mahidol University is situated. All these four provinces are adjacent to the four previously mentioned. Most of the central region is alluvial flatland.

\section{Linguistic Structure of Toponyms}

In 'On geographical names of the Kwakiutl Indians' (1964:171-176), Boas examined the influence of linguistic structure of the Kwakiutl Indian language on the formation of geographical names. After giving examples of suffixation in Kwakiutl, he compared the structure of various geographical names of several American Indian languages, those that have a large number of suffixes, namely Kwakiutl and Eskimo, and those that, in Boas terms, 'compound with ease', e.g., Mexican Nahuatl, Keresan, Zuni, etc. (Boas 1964:175). This led Hymes to state

...that cultural interests are the major factor in terminology, but that the selectivity of linguistic form affects the kinds of terms that occur and their frequency... (Hymes, 164:169).

\footnotetext{
${ }^{6}$ See Thai Cultural Landscape (1996: 259, 311)
} 
As is well known, Thai is a predominantly monosyllabic language. However, semantically unanalyzable polysyllabic words also exist. Moreover, word-compounding and reduplication are very productive processes in Thai. Modifiers follow the words they modify and, of course, the possessor follows the possessed. Thai also has prepositions. While Thai morphology differs from that of English, the Thai sentence has the same basic word order as in English, i.e., Subject-Verb-Object. Thus, we can say that Thai is typologically a $/ \mathrm{SVO} / \mathrm{Pr} / \mathrm{NP} / \mathrm{NA} /$ language.

Given that there is no productive inflection in Thai and that compounding is a very lively process, Thai village names should reflect this linguistic special structure. On the basis of the 4,916 village names in the eight western provinces of Thailand, a village name generally consists of a single word or a compound word.

4.1. Names of a single word. Only a small number of village names have this construction in which bâan 'village' is followed by a modifier:'

บ้านบึง (bâan 'a village' - bin 'large swamp'), บ้านห้วย (bâan 'a village' - hûay 'brook, stream, creek'), บ้านดอน (bâan 'a village' - doon 'highland'), บ้านเก่า (bâan 'a village' kàw 'old'), บ้านบน (bâan 'a village' bon 'upper, on').

7 Pranee Kullavanijya (1992:32) stated that the word 'บ้าน' is the word used in various languages of the Tai Language Family to mean village. It had this same meaning in the older days in Thai, but nowadays the meanings have been narrowed down to mean 'a house, home'. Thus it is possible that all these village names may consist of two nouns or a noun and a preposition or an adjective.
4.2. Names of two words. In this pattern both words are monosyllabic nouns, the first word is usually a geographical term, plant name, or gathering place, and the second word may be a geographical term, plants, animal name, or a descriptive word: หนองทราย (nวัว 'swamp, lagoon, large pool' - saay 'sand'), คลองยาว (khloon 'canal' yaaw 'long'), โพธิ์ใหญ่ (phoo 'Bo tree, Ficus religiosa' - yày 'big'), ตลาด ควาย (talàat 'market' - khwaay 'buffalo'), and ตลาดใหม่ (talàat 'market' - mày 'new').

4.3. Names of two words. The first word is a monosyllabic geographical term or plant name or part (See 5.2.1), and the second word is a bisyllabic compound usually functioning as a modifier of the first: คลองอ่อเรือ (khlos 'canal' - ?ùu + ria 'shipyard + boat'), หนองน้ำข่น (nว้ว 'swamp, lagoon, large pool' - náam + khùn 'water + muddy'), ตอไม้แดง (too 'stump' - máay + dææ 'wood + red'), ไผ่ช้องลม (phày 'bamboo' chôn + lom 'opening, gap + wind').

4.4. Names of three words. The first two words are usually monosyllabic nouns expressing geographical features, plant names/ parts, animals, or gathering places. The third word is a modifier, which may be a monosyllabic word or a compound word, signifying a characteristic, shape, age, direction, or a proper name. Examples are: คลองวัด อบบล (khlos 'canal' - wát 'temple' Pubon 'lotus, Pali'), หนองบางเก่า (nวัs 'swamp, lagoon, large pool' baa 'waterway' - kàw 'old'), บาง สะแกน้อย (baa 'water way' - sakææ 'a kind of tree, Conbretum quadrangulare'- nóวy 'small, little'), หนองนกกระเรียน (nวัว 'swamp, lagoon, large pool' - nók 'bird' - kra 
rian 'sarus crane'), โป่งเก้งพัฒนา (pòo 'salt lick' - kêe 'barking deer' - phat tha naa 'develop, Pali'), ไผ่ตา โม้ (phày 'bamboo' - taa 'grand father' - móo 'proper name').

Given the fact that the Thai are Buddhists, the Pali language, a language of Buddhism, and the Sanskrit language, a language of high formal ceremonies, have had a great deal of influence upon the names of the Thai people, and the names of Thai villages are no exception. Many village names in the eight provinces have Pali or Sanskrit names or Pali or Sanskrit words as modifiers of the head words in the names, for instance: คลองราษฎร์เจริญ (khloo 'canal' - râat 'people, citizen', - ca rəən 'progress, advance'), ห้วยนาคราช (hûay 'brook, stream, creek' - nâak kha râat 'Naga, a legendary serpent'), ร่วมใจพัฒนา (rûam 'join in, participate' - cay 'heart' - phat tha naa 'develop'), ดอน สำราญ (doon 'highland' $-\mathrm{s}$ m raan 'to feel happy, content'), ศรีสำราญ (s i 'splendor, excellence, glory' - s m raan 'to feel happy, content').

In summary, the linguistic structure of all the village names follows those of the basic word order and very productive compounding in Thai. That is, almost all the village names are mono-morphosyllabic; the polymorphosyllabic village names consist of a head word and a modifier; the first is usually a monomorphosyllable, while the second may be monosyllabic word or bisyllabic compound, and if there is a third word, it is usually monosyllabic.

\section{Semantic Domains of Toponyms}

In his 'Reference Note' to Boas (1964:176-181), Hymes recounted that 'Toponymy proper can be taken as the study of linguistic designation for places and other aspects of geographical reference':

Often the interest is historical or local curiosity, but especially when approached in terms of structural analysis, involving the organization of such designations into sets and on the basis of underlying components, the topic broaches the problems of spatial orientation in general, both as a cognitive activity and a factor of social life and cultural values.

Based on the meanings ${ }^{8}$ of the first or the head word of village names, which are generic nouns ${ }^{9}$, there are five major semantic categories or domains as follows:

5.1 'Geographical Features'. This category can be divided into 3 subcategories.

5.1.1 Water, a source of water, or a section of water. From the 4,916 village names, there are 1,941 names beginning with the following 30 morphemes that are related in some way to water:

\footnotetext{
${ }^{8}$ Most of the Thai translations are taken from Haas (1964).

${ }^{9}$ For the analysis of meaning, the study emphasizes the first noun after the word บ้าน / bâan 'village'/ as an initial morpheme of a village name.
} 
1. แก่ง [kæ ] 'rapids'

For example:

แก่งแคบ kæ 'rapids' + khæ̂æp 'narrow

2. ค้ง

แก่งปลากด kæ̀ 'rapids' + plaa - kòt 'cat-fish'

For example:

คุ้งโตนด

[khú ] 'bend of a watercourse'

คุ้งตาแก้ว khú 'bend of a watercourse' + taa 'grandfather' + k̂̂ææw 'a proper name'

3. ค

[khuu] 'ditch'

For example:

คูบว

คูเมือง

4. แคว

For example:

แควน้อย

แควรังใหญ่

5. คงคา

For example: คงคาเหนือ คงคาใต้

6. คลอง

For example:

คลองโพธิ์

คลองตาจุ่น

7. ชำแระ

For example:

ชำแระบน

ชำแระล่าง

8. น้ำ

For example:

น้ำพุ

น้ำโจน

9. น้ำตก

For example:

น้ำตกไทรทอง náam tòk 'water' + say 'banyan tree' + thos 'gold'

10. ทะเล

For example:

ทะเลบก

ทะเลค้าน

11. บาง

For example:

บางช้าง

บางทองหลาง

12. บึง

For example:

บึงหัวแหวน khuu 'ditch' + bua 'lotus'

khuu 'ditch' + maan 'town

[khwææ] 'tributary, branch of a river'

khwææ 'tributary, branch of a river' + nóวy 'small, little'

khwææ 'tributary, branch of a river' + way 'a deep pool (in a large body of water)' + yày 'big, large'

[kho khaa] 'river, sea, the waters; a shortened form for mæ̂æ kho khaa [the goddess of the waters]'

kho khaa 'river, sea, the waters' + ňa 'north'

kho khaa 'river, sea, the waters' + tây 'south'

[khlos ] 'canal'

khlos 'canal' + phoo 'Bo tree'

khlos 'canal' + taa 'grandfather' + cùn 'a proper name'

[cham $r$ ?] 'muddy place'

cham r ? 'muddy place' + bon 'on, over, above'

cham $r$ ? 'muddy place' + lâan 'down, lower'

[náam] 'water'

náam 'water' + phú? 'fountain, spring'

náam 'water' + coon 'jump'

[náam tòkk] 'waterfall'

[tha lee] 'sea'

tha lee 'sea' + bòk 'land'

tha lee 'sea' + kháan 'protest'

[baa ] 'waterway'

baa 'waterway' + cháa 'elephant, metaphorically 'big",

baa 'waterway' + thos lăa 'Erythrina fusca' (a kind of tree)

[bi ] 'large swamp'

bi 'large swamp' + h a 'head' + wæ̌æn 'ring' 
บึงคา bi 'large swamp' + khaa 'Lamperata cylindrica' (a kind of grass)

13. บ่อ

For example:

บ่อพลับ

ป่อน้ำพุ

14. ปลัก

For example:

ปลักเขว้า

[bว̀े]

'well, pond, pit, mine'

bذ̀ 'well, pond; pit, mine' + phláp 'persimmon, Diospyros embryopteris' bว̀o 'well, pond; pit, mine' + náam phú? 'fountain, spring'

[plàk] 'mud hole, mud puddle'

ปลักสะแก

plàk 'mud hole, mud puddle' + khâw 'Adina cordifolia' (a kind of tree) plàk 'mud hole, mud puddle' + sa kææ 'Combretum quadrangulare' (a kind of tree)

15. พัง

[pha ]

'well, puddle'

For example:

พังม่วง

พังตร

16. พุ

For example:

พุน้ำร้อน

พุหวาย

17. แพรก

For example:

แพรกทะเล

pha 'well, puddle' + mûa 'purple; mango'

pha 'well, puddle' +trù? 'jail, prison; tree'

[phú?] 'water spout'

แพรกหนามแดง phrâæk 'fork in waterway' $+\mathrm{n}$ am'thorn' $+\mathrm{dææ}$ 'red'

18. มาบ

For example:

มาบปลาเค้า

มาบแค

phú? 'water spout' + náam 'water' + róon 'hot'

phú? 'water spout' $+w$ ay 'rattan'

[phræ̂æk] 'fork in waterway'

phræ̂æk 'fork in waterway' + tha lee 'sea'

[mâap] 'marshland, low-lying plain'

mâap 'marshland, low-lying plain' + plaa 'fish' + kháw ' - '

mâap 'marshland, low-lying plain' + khææ 'Bignoniaceae'

(a kind of tree)

19. แม่น้ำ

For example:

แม่น้ำน้อย

[mæ̂æ náam] 'river'

20. ราง

For example:

รางมะเดื่อ

mæ̂æ náam 'river' + nóoy 'small, little'

[raaj] 'rail, groove, through'

รางตาบูรณ์

21. ละหาน

For example:

บ้านละหาน

raan 'rail, groove, through' + ma dìa 'fig tree, Ficusglomerata'

raan 'rail, groove, through' + taa 'grandfather' + buun 'a proper name'

22. ลำ

For example:

ลำพยา

[la $\mathrm{h}$ an] 'body of water, rivulet, brook'

ลำท่าโพธิ์

23. ลัด

For example:

ลัดกะปี

baân 'village' + la h an 'body of water, rivulet, brook'

[lam] 'course-way, passageway'

ลัดตาช่วย

lam 'course-way, passageway' + pha yaa ' - '

lam 'course-way, passageway' + thâa 'port, harbor, pier, wharf, landing' + phoo 'Bo tree'

[lát] 'shortcut'

lát 'shortcut' + ka pí 'shrimp paste'

lát 'shortcut' + taa 'grandfather' + chûay 'a proper name' 
24. วัง

For example:

[wa ] 'a deep pool (in a large body of water)'

วังข่อย

wa 'a deep pool (in a large body of water)' + khว̀y 'Strblus asper' (a kind of tree)

วังยาว wa 'a deep pool (in a large body of water)' + yaaw 'long'

25. สระ

For example: [sà?] 'pool, pond'

สระน้ำหวาน sà? 'pool, pond' + náam 'water' + w an 'sweet'

สระสื่มุม sà? 'pool, pond' + sì 'four' + mum 'corner'

26. หนอง [nวัs ] 'swamp, lagoon, large pool'

For example:

หนองอ้อ กวัง 'swamp, lagoon, large pool' + ใิิ 'a reed, Arundo donax'

หนองปลาไหล กวัง 'swamp, lagoon, large pool' + plaa 1 y 'eel'

27. ห้วย

For example:

[hûay] 'brook, stream, creek'

หัวยพลู hûay 'brook, stream, creek' + phluu 'betel-vine'

ห้วยจระเข้ hûay 'brook, stream, creek' + cos ra kheee 'crocodile'

28. อ้อม

[?̂ิom] 'detour'

For example:

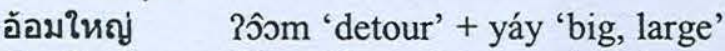

อ้อมโรงหีบ ใิวง 'detour' + roo hìip 'sugar cane mill'

29. อ่าง

[?àan] 'reservoir'

For example:

อ่างหิน ใàa 'reservoir' $+\mathrm{h}$ n 'rock'

อ่างศิลา ใàa 'reservoir' + si laa 'rock (Pali)'

30. อ่าว

For example:

อ่าวใหญ่ ใàaw 'bay' +yày 'big, large'

อ่าวกระบือ ?àaw 'bay' + kra bï 'buffalo'

5.1.2 An area of land of

beginning with one of the following relatively higher elevation compared seven noun morphemes related to to surrounding areas also features in elevated land:

village names. There are 458 villages

1. โคก /khôok/ 'mound, knoll'

For example:

โคกเจ็ดลูก khôok 'mound, knoll' + cèt 'seven' + lûuk 'a classifier'

โคกไผ่

khôok 'mound, knoll' + phày 'bamboo'

2. ดอน /doon/ 'highland'

For example:

ดอนโพธิ์ doon 'highland' + phoo 'Bo tree'

ดอนยายเหม doon 'highland' + yaay 'grandmother' + hěem 'a proper name'

3. เนิน /nəən/ 'knoll, mound'

For example:

เนินทราย

nəən 'knoll, mound' + saay 'sand'

เนินรัก

nəən 'knoll, mound' +rák 'love; Calotropis gigantea' (a kind of a flowering shrub, the black varnish tree) 
4. โนน /noon/ 'highland, hills'

For example:

บ้านโนน bâan 'village' + noon 'highland, hills'

5. เขา /kh w/ 'mountain, hill'

For example:

เขาย้อย $\mathrm{kh} \mathrm{w}$ 'mountain, hill' + yóวy 'trickle down'

เขาพระ $\mathrm{kh}$ w 'mountain, hill' + phrá 'monk'

6. พนม /pha nom/ 'mountain' (Khmer)

For example:

พนมนาง pha nom 'mountain' + naay 'woman, Mrs.'

พนมทวน pha nom 'mountain' + thuan 'lance; go against; contrary'

7. ภู /phuu/ 'mountain, short form of phuu khăw'

For example:

ภูเตย phuu 'mountain' + təəy 'Pandanus helicopus'

5.1.3 Other geographical areas. There are 488 village names in this subcategory. Three morphemes in this sub-category are defined in terms of a body of water.

1. เกาะ /kj̀?/ 'island'

For example:

เกาะสะเดิ่ง kว̀? 'island' + sa də̀ 'a Karen name for a kind of tree'

เกาะลอย kว̀? 'island' + looy 'float'

2. แหลม /læ̌æm/ 'cape, peninsula'

For example:

แหลมทอง læææm 'cape, peninsula' + thoon 'gold'

แหลมมะเกลือ læ̌m 'cape, peninsula' + ma klia 'ebony, Diospyros mollis'

3. ท่า /thâa/ 'port, harbor, pier, wharf, landing'

For example:

ท่าคอกวัว thâa 'port, harbor, pier, wharf, landing' + khôsk 'pen, shed' + wua 'cow'

ท่าข้าม thâa 'port, harbor, pier, wharf, landing' +khâam 'to cross'

Four morphemes are generic nouns signifying lowland or basin:

1. ทุ่ง /thû / 'field, meadow, open field'

For example:

ทุ่งสมอ

thû 'field, meadow, open field' + sa mว̌o 'myrobalan' (a kind of tree)

ทุ่งต้นไทร thû 'field, meadow, open field' + tôn 'tree' + say 'banyan tree'

2. ลาน /laan/ 'an open, wide, level area'

For example:

ลานคา

laan 'an open, wide, level area' + khaa 'Lamperata cylindrica'

(a kind of grass)

ลานตากฟ้า laan 'an open, wide, level area' +taak 'spread out' + fáa 'sky'

3. ลาด /lâat/ 'slope, incline'

For example:

ลาดหญ้า lâat 'slope, incline' +yâa 'grass'

ลาดบัวขาว lâat 'slope, incline' + bua 'lotus' + kh aw 'white'

4. ลุ่ม /lûm/ 'lowland, basin'

For example: 
ลุ่มโพธิ์ lûm 'lowland, basin' + pho 'Bo tree'

Six noun morphemes in this sub-category designate caves, ridges and related features of rock formations:

1. ถ้ำ /thâm/ 'cave'

For example:

ถ้ำเสือ thâm 'cave' + š̌a 'tiger'

ถ้ำหิน thâm 'cave' + $\mathrm{h}$ n 'rock'

2. ผา $/ \mathrm{ph}$ a/ 'cliff'

For example:

ผาปก $\quad \mathrm{ph}$ a 'cliff' + pòk 'to cover'

3. สัน $/ \mathrm{s} \mathrm{n} /$ 'mountain ridge'

For example:

สันพะนอม $\mathrm{s} n$ 'mountain ridge ' + pha noom 'sovereign mountain'

4. หิน $/ \mathrm{h} \mathrm{n} /$ 'rock'

For example:

หินดาด h n 'rock' + dàat 'to spread out; level'

หินแหลม $\mathrm{h} \mathrm{n}$ 'rock' + læææm 'pointed'

5. หุบ /hùp/ 'valley'

For example:

หุบพริก hùp 'valley' + prîk 'hot pepper, chilli'

หุบกระทิง hùp 'valley' + kra thin 'bull'

6. อุโมงค์ /Ru mooy/ 'tunnel'

For example:

บ้านอุโมงค์ baân 'village' + ?u moon 'tunnel'

There are two noun morphemes which refer to land areas along the canals, rivers, or sea:

1. ตลิ่ง /talì/ 'bank (of a river or canal)'

For example:

ตลิ่งชัน talì 'bank (of a river or canal)' + chan 'steep'

ตลิ่งแดง talì 'bank (of a river or canal)' + dææ 'red'

2. หาด /hàat/ 'beach'

For example:

หาดสำราญ hàat 'beach' + sam raan 'to be gay (Pali)'

หาดบางแก้ว hàat 'beach' + baa 'waterway' + kæ̂æw 'glass'

There are five noun morphemes which refer to an opening or a passageway through land or water:

1. ทาง /thaan/ 'way'

For example:

ทางหลวง thaan 'way' +1 an 'royal'

2. ช่อง /chô / 'opening, hole (through something)'

For example:

ช่องลาภ chô 'opening, hole (through something)' + lâap 'fortune'

ช้องลม chô 'opening, hole (through something)' + lom 'wind'

3. ตรอก /tròs/ 'lane, alley'

For example:

ตรอกมะตูม trò่k 'lane, alley' + ma tuum 'bale fruit, Aegle marmelos' 
ตรอกหัวสะพาน tròsk 'lane, alley' $+\mathrm{h}$ a 'head' + sa phaan 'bridge'

4. สะพาน /sa phaan/ 'bridge'

For example:

สะพานเจ็ก sa phaan 'bridge' + cék 'Chinese'

สะพานหิน sa phaan 'bridge' + h n 'rock'

5. โกรก /kròk/ 'gorge, ravine, gully, canyon'

For example:

โกรกสิงขร kròk 'gorge, ravine, gully, canyon' + $\mathrm{s}$ j khoon 'mountain (Pali)'

โกรกยาว kròk 'gorge, ravine, gully, canyon' + yaaw 'long'

The last miscellaneous subcategory includes four morphemes:

1. คัน /khan/ 'dike, earthen embankment enclosing a paddy field'

For example:

คันลำ khan 'dike, earthen embankment enclosing a paddy field' + lam

'course-way, passageway'

คันลาง khan 'dike, earthen embankment enclosing a paddy field' + laan 'omen'

2. โป่ง /pòn/ 'salt-lick, a place in which the earth is saline'

For example:

โป่งช้าง

pòon 'salt-lick, a place in which the earth is saline' +cháan

'elephant'

โป่งหวาย pòn 'salt-lick, a place in which the earth is saline' + w ay

'rattan'

3. หลุม $/ 1 \mathrm{~m} /$ 'hole'

For example:

หลุมรัง $1 \mathrm{~m}$ 'hole' +ran 'lump laterite' (a kind of a large tree)

หลุมหิน $1 \mathrm{~m}$ 'hole' $+\mathrm{h}$ n 'rock'

4. หย่อม /yòm/ 'patch, cluster, clump'

For example:

บ้านหย่อม bâan 'village' + yòm ' patch, cluster, clump'

5.2 'Non-geographical Features'. This dimension has been subdivided into eight subcategories:

5.2.1 Plants. There are 383 village names that begin with plant names or common nouns referring to plants or parts of the plants, e.g. ต้น มะพร้าว /tôn 'a classifier for 'tree' maphráaw 'coconut'/, ดงไม้แดง /do 'forest, jungle' - máy + dææ 'tree + red'/, โพธิ์งาม /phoo 'Bo tree' - aam 'beautiful'/, ไผ่โทน /phày 'bamboo' thoon 'single, only', ตาลเจ็ดยอด /taan 'sugar palm' - cèt 'seven' - yôt 'tip'\%.
5.2.2 Animals. Only 34 village names out of 4,916 names begin with animal names, such as: เต่าดำ /tàw 'turtle' - dam 'black'/, มด แดง /mót 'ant' - dææ 'red'/, กระต่าย เต้น /kra tàay 'rabbit' - tên 'dance'\%.

5.2.3 Uncultivated and cultivated lands. Generic nouns in this sub-category refer to land areas having to do with vegetation, and whether they are cleared or not cleared for cultivation. Included in this sub-category are generic nouns for various occupations. There are 337 village names beginning with one of the following nine noun morphemes: 
1. ไร่ /rây/ 'farm, plantation'

For example:

ไร่กล้วย

rây 'farm, plantation' + klûay 'banana'

ไร่ดอน

2. นา /naa/

For example:

นาไทร

นางาม

3. ป่า /pàa/

For example:

ป่าแก

ป่าไกล

4. ดง /do /

rây 'farm, plantation' + doon 'highland'

'paddy field'

naa 'paddy field' + say 'bayan tree'

naa 'paddy field' + naam 'beautiful'

'forest'

pàa 'forest' + kææ 'Combretum quadrangulare' (a kind of tree)

pàa 'forest' + klay 'far'

For example:

ดงไม้แดง

do 'jungle' + máy 'wood' + dææ 'red'

ดงยาง

5. ชัฏ/chát/

For example:

ชัฏดงพลับ

do 'jungle' + yaa 'a timber tree, Dipterocarpus turbinatus' 'dense jungle, deep forest (mostly used in written literature)'

chát 'dense jungle, deep forest (mostly used in written literature)'

+ do 'thick forest' + phláp 'persimmon Diospyros embryopteris'

ชัฏป่าหวาย chát 'dense jungle, deep forest (mostly used in written literature)'

+ pàa 'forest' + w ay 'rattan'

6. ไพร /phray/ 'forest, jungle'

For example:

ไพรงาม phray 'forest, jungle' + aam 'beautiful'

ไพรสะเดา phray 'forest, jungle' + sa dau 'a neem tree Azadirachta indica'

7. พง /pho / 'brush, thicket'

For example:

พงตึก pho 'brush, thicket' + tik 'building'

8. สวน /s an/ 'garden, plantation'

For example:

สวนถั่ว

$\mathrm{s}$ an 'garden, plantation' + thùa 'pea, bean'

สวนตะไคร้ $s$ an 'garden, plantation' + ta khráy 'galangal'

9. คอก /khǒok/ 'enclosure, pen, sty; stable, cowbarn'

For example:

คอกช้าง

khว̌ok 'enclosure, pen, sty; stable, cowbarn' + cháa 'elephant'

คอกสะแกวัลย์ khว̌วk 'enclosure, pen, sty; stable, cowbarn' + sa kææ wan ' - '

A few noun morphemes designate occupations in which are included the terms ครก /khrók 'mortar'/, เตาอิฐ /taw 'stove' - ?it 'brick'/, เตาปูน /taw 'stove' - puun 'lime'/.

1. ตลาด /talàat/ 'market'

For example:

ตลาดใหม่ talàat 'market' + mày 'new'

ตลาดศรีประจันต์ talàat 'market' $+\mathrm{s}$ i pra can ' - '
5.2.4 Constructed objects or gathering places. Common noun morphemes that refer to constructed objects or gathering places or to both occur in 291 village names which begin with one of following noun morphemes: 
2. สำนัก /s m nák/ 'lodging place; residence'

For example:

สำนักเย็น $s$ m nák 'lodging place; residence' + yen 'cold'

สำนักคร้อ S m nák 'lodging place; residence' + khrós 'a species of tree'

3. ศาล $/ \mathrm{s}$ an/ 'small shrine in the form of a house, intended as a residence for a spirit'

For example:

ศาลเจ้างิ้ว $s$ an 'small shrine in the form of a house, intended as a residence

for a spirit' + câw 'god' + îw 'Chinese opera'

4. ศาลา /s a laa/ 'pavilion, hall'

For example:

ศาลายา $\mathrm{s}$ a laa 'pavilion, hall' + yaa 'medicine'

ศาลาท่าทราย S a laa 'pavilion, hall' + thâa 'pier, landing' + saay 'sand'

5. โรง /roo / 'building, structure (normally not used alone except as a classifier)'

For example:

โรงกุ้ง roo 'building, structure (normally not used alone except as a

classifier)' + kû 'shrimp'

โรงฟืน roo 'building, structure (normally not used alone except as a classifier)' + fin 'firewood'

6. ทับ /tháp/ 'dwelling place'

For example:

ทับศิลา tháp 'dwelling place' + si laa 'rock (Pali)'

ทับซุง tháp 'dwelling place' + su 'timber'

7. สนาม /san n am/ 'lawn, yard'

For example:

สนามแย้ $\quad \operatorname{san} n$ am 'lawn, yard' + yǽæ 'ground lizard, Liolepis belliana'

8. อู่ /Rùu/ 'place where something is harbored, cradled, stored'

For example:

อู่ตะเภา ใùu 'place where something is harbored, cradled, stored' + ta phaw 'Chinese junk'

อู่ยา ใùu 'place where something is harbored, cradled, stored' + yaa 'medicine'

9. นิคม /ni khom/ 'settlement'

For example:

นิคมสหกรณ์ ni khom 'settlement' + sa ha koon 'co-op'

10. วัด /wât/ 'temple'

For example:

วัดไทร wât 'temple' + say 'banyan tree'

วัดบางใหญ่ wât 'temple' + baa 'waterway' + yày 'big, large'

11. เวียง /wia / '(archaic, dialect) city, town'

For example:

เวียงคอยล่าง wia '(archaic, dialect) city, town' + khวэy 'wait' + kâa 'under'

เวียงคอยบน wia '(archaic, dialect) city, town' + khəoy 'wait' + bon 'on'

Finally, the study discovered just a few other morphemes with one or two occurrences in place names.
5.2.5 Numbers. Village names in this sub-category begin with cardinal numbers, such as สอง /sวว 'two'/, สาม /s am 'three'/, สื่ / sìi 
'four'/, and are followed by classifiers. The village names in this sub-category have exactly the same construction as those of the numeral noun phrase in Thai with y้าน/bâan 'a village'/ as a head word followed by numbers and classifiers, for example, บ้านเก้าหลัง /bâan 'a village' - kâaw 'nine' - lăy 'classifier for house'/, บ้านสองห้อง /bâan 'a village' - sรว 'two' - hôy 'room'/, บ้านสี่แยก /bâan 'a village' - sìi 'four' - yæ̂æk 'intersection'/, บ้านสองพี่น้อง /bâan 'a village' - š̌ว 'two' -phîi nós 'cousins, relatives'\% There are also village names with numbers that have the construction of bâan 'a village' classifier - number, e.g., บ้านหลักสอง /bâan 'a village' - làk 'pole, pillar' sว ว 'two'/, บ้านเสาร์ห้า /bâan 'a village' - s w 'Saturn' - hâa 'five'/, บ้านกิโลแปด /bâan 'a village' - kilo 'kilometer' - p æt 'eight'\%.

\subsubsection{Persons. A good} number of the village names in the eight provinces include what may be a name or an official title of a person; the name may refer to a former owner, a person who used to live there, a person first situated there, or a representative from the central administration. The name is usually preceded by a generic noun morpheme, such as: ตา /taa 'grandfather'/, ยาย /yaay 'grand-mother'/, นาง /naan 'title placed before the first name of a married woman, Mrs. + Proper name'/, แม่ /mæ̂æ 'mother'/, e.g., ตาก้อง /taa 'grand-father' - kôs 'proper name'/, ยายแพง /yaay 'grandmother' - phææ 'proper name'/, นาง บวช /naa 'Mrs.' -bùat 'proper name'/, แม่ประจันต์ /mæ̂æ 'mother' pracan 'proper name'/, จางวาง /caa waa 'chief of attendants'/, ขุนโสน $/ \mathrm{kh} \mathrm{n}$ 'title for the lowest rank of conferred nobility' $-\mathrm{s}$ on 'proper name'\%.
5.2.7 Other ethnic languages. The village names, especially those in Kanchanaburi province, are either of Karen or Mon origin. ${ }^{10}$ Many Karen and Mon people have come from Myanmar and settled in Kanchanaburi since the final period of the Ayudhaya reign (around 1584 $\mathrm{AD}$.) and the beginning period of the Rattanakosin reign (around 1815 AD.). Nowadays, most of them are Thai citizens but the village names are fixed; the place names are more permanent than the people who lived there. A lot of people who live in the village close to town at present may be descendants of the Karen or the Mon, but a few of them are not. Those who live in the remote areas are mostly of mixed ancestry whose forbears migrated long ago, but some are people who migrated relatively $\begin{array}{lll}\text { recently (around } 1948 & \mathrm{AD} \text {.). }\end{array}$ Examples of Mon and Karen Village names are: วังกะ /wan 'a deep pool (in a large body of water)' - ka 'fish (a Mon word meaning fish')/, ซองกาเรีย /so ka ria 'a Mon word meaning the side or that side'/, ไล่โว /lây wôo 'a Karen word meaning 'red cliff'/, สเน่ห์พ่อง/sa nee pho a Karen word meaning landing or pier for bamboo rafts/ (See Appendix II).

5.2.8 Other ethnic groups. The village names can also tell us something about the ethnic groups who live there and, of course, their cultural heritage. The names in this sub-category are Thai names for other ethnic groups, ${ }^{11}$ while those in 5.2.7

${ }^{10}$ See Sujaritlak Deepadung (2001) on village names in Kanchanaburi Province, paper presented at the SEALS XI Conference.

"The morphem ยาง (yaa ) in Thai has two meanings 1) a kind of plant and 2) the Thai word for Karen people. In this study, the village names with 'yaa' are 
above are village names in ethnic languages. Names in this subcategory are: แขก /kh æk 'an Indian'/, รามัญ /raaman 'a Mon'/, ละว้า /la wáa 'a lawa'/, ชาวเหนือ /chaaw 'inhabitant of, dweller in' n-a 'north'/, กะเหรี่ยงโปร่ง / $\mathrm{ka}$ rìa 'a Karen' - pròo 'clear'/, เก่ากะเหรี่ยง /kàw 'old' - ka rìa 'a Karen'\%.

5.3 Locatives or Directional Features. Two sub-categories are in this dimensions:

5.3.1 Noun locatives. Noun locatives are words that normally are nouns. Body part terms are extended to denote the shape and locations of villages in relation to various geographical features or gathering places. This is a metaphorical extension of the body-part terms to spatial relational uses, which is a common practice for village names of the eight provinces studied here. For example: ปาก /pàak 'mouth'/, ท้อง /thóon 'stomach'/, หน้า /nâa 'face'/, ไหล่ /lày 'shoulder'/, คอ /khวo 'neck'/, หลัง $/ 1$ 'back'/, หัว $/ \mathrm{h}$ a 'head'/, ตีน /tiin 'foot'/, as in: ปาก คลองเขาดิน /pàak 'mouth'- khlos 'canal'- kh w 'mountain' - din 'soil'/, ท้องคุ้ง /thว́s 'stomach' - khú 'bend of a water course'/, หน้าวัด /nâa 'face'- wát 'temple'/, ไหล่นำ /lày 'shoulder' - náam 'water'/, คอราง /khoo 'neck' - raa 'rail'/, หลังโรงหีบ /1 'back' - roo 'building' - hìp 'press, squeeze, crush'/, หัวป่า $/ \mathrm{h}$ a 'head' - pàa 'forest'/, ตีนเนิน/tiin 'foot' - nəən 'hill'\%

classified as plants. If there is a field research for further study in these area of Prachuap Khiri Khan, Phetchaburi and Ratchaburi, special emphasis should be on the origin of the morpheme 'yaa ' in village names of the three mentioned provinces.
Noun locatives can occur before another generic noun in village names: ต้น /tôn 'classifiers for trees; trunk, stalk; beginning, source'/, ปลาย /plaay 'end, tip'/, ท้าย /tháay 'rear, end'/, ริม /rim 'edge, edging rim'/, ฝ่ง /fà 'shore, bank'/, ชาย /chaay 'edge, border'/, ขอบ /khว̀วp 'edge, rim'/, ข้าง /khâa 'side'/, ฝ่าย /fàay 'side'/, ฟาก /fâak 'side; shore, bank'\%.

Examples are: ปลายคลอง /plaay 'end, tip'- khlos 'canal'/, ท้ายเกาะ/tháay 'rear, end' - ko? 'island'/, ริมคลอง /rim 'edge, edging rim' - khlos 'canal'/, ฝั่งเกาะบน / fà 'shore, bank' - ko? 'island' - bon 'upper'/, ชายทะเล โรงกุ้ง /chaay 'edge, border' - tha lee 'sea' - roo kû 'building + shrimp'/, ขอบลาด /khว̀วp 'edge, rim' - lâat 'slant, slope'/, ข้างวัด /khâa 'side' wát 'temple'/, ฝ่ายท่า /fàay 'side' thâa 'port; pier'/, ฟากหนอง /fâak 'side; shore, bank' - nǒs 'swamp, lagoon, large pool'\%

Directional nouns, such as เหนือ /n-a 'north'/, ใต้ /tây 'south'/, ตะวันออก /ta wan ?ว̀े 'east'/, and ตะวันตก / ta wan tòk 'west'/, can also precede or follow the other noun morphemes in village names or be a village name by itself. For example:

เหนือวัด /n-a 'north' - wat 'temple'/, ใหม่เหนือ /mày 'new' - n-a 'north'/, บ้านใต้ /bâan 'a village' - tây 'south'/, ขลู่ใต้ /khlùu 'Pluchia indica' - tây 'south'/, ใด้เหมืองใหม่ / tây 'south' mła 'mine' - mày 'new'/.

5.3.2 Prepositional locatives. Locative words in this case are prepositions. In village names that include prepositional locatives the morpheme บ้าน /bâan 'a village'/ is followed by a preposition as in บ้าน นอก /bâan 'a village' - nôวk 'outside'/, บ้านใน /bâan 'a village' nay 'in, inside'/, บ้านกลาง /bâan 'a 
village' - klaa 'in the middle'\% These prepositional locatives may also follow or precede other geographical terms or gathering places, such as หนองสะเดาบน /nวัง 'swamp, lagoon, large pool' - sa daw 'Neem tree, Azadirachta indica'- bon 'upper'/, ตลาดล่าง /talàat 'market' lâa 'lower'/, บึงนอก $/ \mathrm{bi}$ 'large swamp' - nôok 'outside'/, ในคู /nay 'in, inside' - khuu 'ditch'/, บนดอน /bon 'upper' - doon 'highland'/.

5.4 'Auspicious Features'. As mentioned earlier, Pali and Sanskrit are the languages of Buddhism and religious ceremonies. They are regarded by the Thai people as the languages symbolizing good luck, prosperity and progress. Most of the newly coined village names are in either Pali or Sanskrit. Some of the old names may be changed from the original Thai names to either Pali or Sanskrit. There are village names of this sub-category in every province, for example: สามัคคีธรรม /saa mák khii 'unify, harmony' - tham 'dharma, Buddhist teaching'/, สว่าง อารมณ์ /sa wàa 'light' - ?aa rom 'mood, emotion'/, ศรีเมือง /s i 'splendor, excellence, glory' - mia 'city, town'/, ประชาชื่น /pra chaa 'population' - chîin 'lively'/, สุขเกษม /sùk 'happy' - ka seem 'merry, happy, joyous'\%.

5.5 'Descriptive Features'. Adjectives or adjectival verbs can occur alone as village names, i.e., they modify the generic name บ้าน /bâan 'a village'/, or occur after the terms for other geographical or non-geographical features. ${ }^{12}$ They are words that

12 These descriptive terms that occur alone as the names of villages are included in the unclassifiable group since there are not many of them. indicate the size, age, or some indicate other states, such as depth, beauty, etc. Examples are บ้านใหม่ /bâan 'a village' - mày 'new'/, บ้านบึง ใหม่ /bâan 'a village' - bỉ 'swamp' mày 'new'/, บ้านเก่า / bâan 'a village' - kàw 'old'/, ไร่เก่า /rây 'field' - kàw 'old'/, ทุ่งใหญ่ /thû 'field' - yày 'big'/, หัวป่าน้อย $/ \mathrm{h}$ a 'head' - pàa 'forest' - nóวy 'little'/, หัวป่าเล็ก /h a 'head' - pàa 'forest' - lék 'small'\%

As one can see, most of the village names follow the basic noun phrase construction in Thai, i.e., with the head noun followed by the qualifier. However, there are some village names in which the qualifier precedes the noun. In Nakhon Pathom province, the two frequently used morphemes are ใหม่ /mày 'new'/, เด่น /dèn 'dominant'/, as in: ใหม่โพธิ์ศรี / mày 'new' - phoo 'Bo tree' - s i 'splendor, excellence, glory'/, ใหม่ หนองจิก /mày 'new' - nว̌s 'swamp, lagoon' - cik 'Indian Oak, Baringtonia Coccinea'/, เด่นทราย /dèn 'dominant' - saay 'sand'/, เด่นมะขาม /dèn 'dominant' - ma kh am 'tamarind'\% This fronted construction, the construction with fronted descriptive qualifier, occurs as a basic form in Thai when more emphasis is put on the qualifiers.

There are also miscellaneous village names of unidentifiable or questionable origin. The meanings of these names are unknown. Some names may be from the dialectal lexicon, some may have undergone substantial change, and some may be errors on the part of local officials. If further and more in-depth investigation is done in the field, all of these miscellaneous items could be classified (See Appendix III). Also, several items that are already classified may be classified in other 
ways. Finally, all of the categories above together with their frequency of occurrence in each province are summarized in Table 1.

Table 1 presents a frequency count of the semantic domains of generic nouns used as the initial morpheme in village names for the eight provinces. The first column is a list of semantic domains from the highest frequency of the generic noun morphemes of water, source of water, or section of water to the lowest frequency for those indicating openings or passageways.

Table 1: $\quad$ Frequency count of semantic dimensions of generic nouns used as initial morphemes in village names for the eight Thai provinces ${ }^{13}$

\begin{tabular}{|c|c|c|c|c|c|c|c|c|c|c|}
\hline Provinces: & 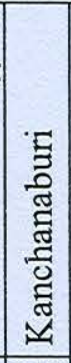 & 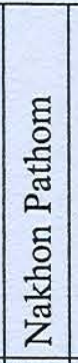 & 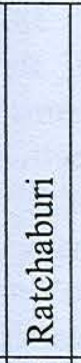 & 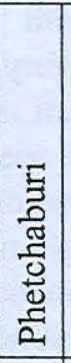 & 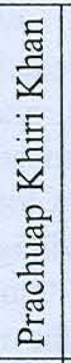 & 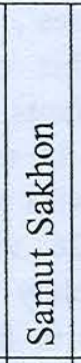 & 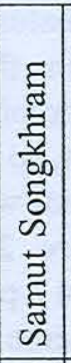 & 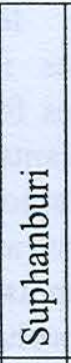 & 푱 & 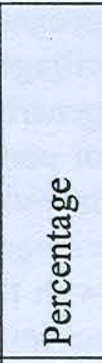 \\
\hline ce of water & 319 & 372 & 351 & 205 & 123 & 110 & 166 & 295 & 1,941 & 39.48 \\
\hline 2. Othe & 122 & 91 & 89 & 57 & 32 & 15 & 10 & 100 & 516 & 10.50 \\
\hline 3. Elevated land areas & 74 & 51 & 106 & 49 & 35 & 20 & 6 & 119 & 460 & 9.36 \\
\hline 4. Plants & 46 & 82 & 59 & 40 & 31 & 12 & 13 & 104 & 387 & 7.87 \\
\hline 5. Unc & 26 & 40 & 54 & 105 & 35 & 14 & 5 & 36 & 315 & 6.41 \\
\hline 6. Others* & 35 & 59 & 56 & 23 & 34 & 33 & 15 & 55 & 310 & 6.30 \\
\hline 7. Unc & 37 & 80 & 34 & 48 & 18 & 12 & 11 & 67 & 307 & 6.25 \\
\hline 8. Locatives or directions & 34 & 18 & 68 & 55 & 23 & 46 & 23 & 29 & 296 & 6.02 \\
\hline 9. Constructed objects or gatherin & 23 & 52 & 61 & 34 & 19 & 25 & 30 & 47 & 291 & 5.92 \\
\hline 10. Animals & 2 & 5 & 6 & 3 & 2 & 3 & 2 & 11 & 34 & 0.69 \\
\hline 11. Other ethn & 31 & - & - & - & - & - & - & - & 31 & 0.63 \\
\hline 12. Openings or passageways & 12 & - & 2 & 11 & 2 & - & - & 1 & 28 & 0.57 \\
\hline Total & 761 & 850 & 886 & 630 & 354 & 293 & 278 & 864 & 4,916 & 100 \\
\hline
\end{tabular}

* That is, Numbers, Persons, Other ethnic groups, and Auspicious forms.

${ }^{13}$ If the study includes the second morpheme of a village name, the frequency count will be different. 
From Table 1 we observe that the three semantic domains with the highest frequency belong to the domain of 'geographical features'. That is, of the total of 4,916 village names 1,941 names have an initial morpheme that signifies water, a source of water, or a section of water; 516 names signify other geographical areas, and 460 names signify elevated land areas. The fourth-ranked semantic domain belongs to the 'nongeographical features', with 387 village names in this category, the generic names for plants, plant names or parts of plants, to be more specific. In Nakhon Pathom with a total of 850 villages there are 26 village names with the noun ไผ่ / phày 'bamboo'/ as an initial morpheme in the names. In Suphanburi with a total of 864 names, there are also 26 villages with the noun ไผ่ /phày 'bamboo'/ and 22 villages with the noun โพธิ์/phoo 'Bo tree' $\%$ The fifth semantic domain includes generic nouns for uncultivated or cultivated land, and there are 315 village names in this category. We may conclude that village names of the eight provinces emphasize the salient geographical features of the landscape and tell us about the villagers' activities of the area.

Village names in the sixth semantic domain include 310 names for numbers, persons, other ethnic groups, and auspicious terms. Unclassified items occupy the seventh semantic domain. As mentioned earlier, the village names included here are unidentifiable and have questionable origins. Locatives and directional morphemes are in the eighth category with 296 village names from the total of $4 ; 916$. The village names that begin with morphemes signifying constructed objects or gathering places occur in the ninth ranked semantic domain with 291 names. Only 34 village names include animal names and this semantic domain is ranked tenth. Village names from ethnic languages rank number eleventh with 31 villages, and all are in Kanchanaburi province. The twelfth and last ranked semantic domain includes 28 village names with morphemes signifying openings or passageways.

\section{Village names and spatial orientation.}

Village names are closely related to the geographical features of the area and ways of living. A few generic nouns of water, section of water, or a body of water can demonstrate the connection among linguistic forms, village names, and the environment. The following discussion focuses on the four generic nouns chosen from the first seven, namely, คลอง /khlos 'canal'/, บาง /baa 'waterway, locality along the waterway'/, หนอง /nวัว 'swamp, lagoon, large pool'/, and หัวย /hûay 'brook, stream, creek'/. Table 2 shows the number of occurrences of nǒs, khlos, baa and hûay in the village names of the eight provinces. 
Table 2: Numerical distribution of terms of ñ̌o, khlos, baa and hûay in eight provinces.

\begin{tabular}{|c|c|c|c|c|c|c|c|c|c|}
\hline & 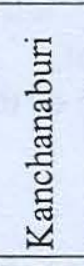 & 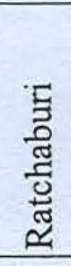 & 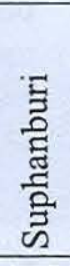 & 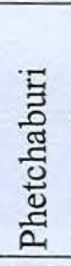 & 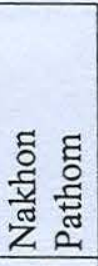 & 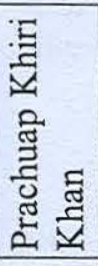 & 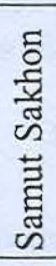 & 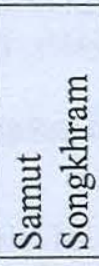 & 㔄 \\
\hline กวัว & 178 & 147 & 139 & 103 & 87 & 74 & 15 & 2 & 743 \\
\hline khlos & - & 52 & 17 & 9 & 110 & 6 & 58 & 100 & 357 \\
\hline $\mathrm{baa}$ & - & 23 & 30 & 20 & 57 & 3 & 21 & 55 & 209 \\
\hline hûay & 30 & 39 & 15 & 15 & 23 & 17 & - & - & 134 \\
\hline
\end{tabular}

From Table 2 the four morphemes are ordered from the highest number of occurrences to the lowest. All four morphemes occur in the provinces of Nakhon Pathom, Ratchaburi, Phetchaburi, Prachuap Khiri Khan, and Suphanburi. Three morphemes, khloo, baa and nǒon, occur in Samut Songkhram and Samut Sakhon, but only two, nǒon and hûay, occur in Kanchanaburi.

Map 1 shows how the eight provinces are physically located next to one another in the western region of Thailand. ${ }^{14}$ Map 2 shows the main waterways $(\boldsymbol{l})$, the ones with water all year round $(I)$ and those with no water during the dry season (/) spread all over the region, especially in Nakhon Pathom, Samut Sakhon, Samut Songkhram, Ratchaburi, Phetchaburi. In Maps 3 and 4, we see the distribution of villages beginning with the generic nouns khlos and baa concentrated in the area of Nakhon Pathom, Samut Sakhon, and Samut Songkhram, but sparsely distributed in some areas of Ratchaburi, Phetchaburi and

14 Thanks to the Ethnolinguistic Map Project, Mahidol University and Mr. Isra Choosri for the six maps.
Suphanburi, and none in Kanchanaburi. The physical locations of villages that begin with the generic nouns khlos and baa conform with the main characteristics of the central alluvial flatland area. According to Ratchabandittayasathan (1982: 169, 467), both khloon and baan have some connections with rivers or seas.

Maps 5 and 6 illustrate the distribution of villages beginning with the generic nouns hûay and nǒon. There are no villages with the generic noun hûay in Samut Sakhon and Samut Songkhram. This is no surprise since the definition of hûay is that it flows from the mountains (Ratchabandittayasathan, 1982:847), and physically there are no hills or mountains in Samut Sakhon and Samut Songkhram. Except for the two provinces already mentioned, we see villages beginning with the generic nouns hûay and nǒon are scattered all over the region. It can be pointed out here is that nǒn has the highest frequency of occurrence among the four generic nouns. Ratchabandittayasathan (1982:831) defines this word with just a synonym. This generic noun seems to signify neither a particular source, section, or outlet of water, nor a 
shape or size of the body of water. It also does not tie up physically with either the north, east, west, south or central region but only tells us where there is water, there are villages.

\section{Conclusions}

In terms of linguistic structure, the village names in the eight provinces of Thailand reflect very well the basic characteristics of the Thai language: the monosyllabic structure, the rich compounding, word order with the head noun followed by modifiers. On the basis of analysis using 'semantic

\section{References}

Boas, Franz. 1964. "On geographical names of the Kwakiutl Indians" In Hymes 1964: 1964-1971-76 (and 'Reference Notes' 176-81).

Department of local Administration. 1992. Tham-niap Thongthii $2535 B C$. Ministry of Interior.

Gainey, Jerry W. 2527. Toponyms in Eastern and Southeastern Thailand: a Preliminary study of village names in chonburi, Rayong, Chantaburi and Trat. ศาสตร์แห่งภาษา 4.1-35.

Haas, Mary. 1964. Thai-English Students' Dictionary. Stanford: Stanford University Press.

Hymes, Dell. 1964. Language in Culture and Society: A Reader in linguistics and anthropology. New York: Harper and Row. feature' domains, village names rely significantly on the physical geography of the area in which they occur; they tell us much about the environment, geographical, and cultural life of the people who live in the area.

I would like to thank audiences of the $11^{\text {th }}$ Southeast Asian Linguistic Conference (SEALS 11) and of the $8^{\text {th }}$ International Conference on Thai studies, especially Acharn Amara Prasithrathasint, for their suggestions.

Pranee Kullavanijja. 1992. Village names in Quangxi Province and the Northeastern Part of Thailand. Bangkok: Chulalongkom University Press. (In Thai)

Royal Institute, The. 1982. Potchananukrom chabap Ratchabandittayasathaan 1982. $1^{\text {st }}$ edition.

Bangkok: Aksoncharoenthat.

Sujaritlak Deepadung. 1999. The Mons: Social, Cultural, Continuity and Change during the 200 years of Rattanakosin. Bangkok : Duantula Publishing. (In Thai)

2001. "The nature of Thai village names: a case study of Kanchanaburi Province" Paper presented at the $11^{\text {th }}$ Southeast Asian Linguistic Conference (SEALS 11). Bangkok, Thailand. 


\section{Appendix I}

Keys to Code Letters and Numbers:

Abbreviations for provinces/จังหวัด - can - wàt/:

กจ: กาญจนบุรี (Kanchanaburi)

นฐ:นครปฐม (Nakhon Pathom)

รบ:ราชบุรี (Ratchaburi)

พบ:เพชรบุรุ (Phetchaburi)

ปจ:ประจวบคีรีขันธ์ (Prachaub Khiri Khan)

สส:สมุทรสาคร (Samut Sakhon)

สค:สมุทรสงคราม (Samut Songkhram)

สพ:สุพรรณบุรี (Suphanburi)

Thai alphabets for districts / อำเภอ - ?am - phəa/

For example, there are11 districts in Kanchanaburi province:

ก: Muang district of Kanchanaburi

ข: Tha ma $\mathrm{ka}$

ค: Tha muang

ง: Bo ploy

จ: Pha nom thuan

ฉ: Sai yok

ช: Thong pha phum

ซ: Sangkhla buri

ฌ: Lau khwan

ญ: Sii sawat

ฎ: Dan makham tia

Numbers for sub-district/ตำบล - tam - bon/

For example, there are 11 sub-substricts in Muang district of Kanchanaburi province:
$1:$ ต่าบลหนองบัว / tam bon-nŏ bua /
2 : ตำบลเกาะสำโรง / tam bon-ko sam roon /
$3:$ ต่าบลหนองหญ้า / tam bon-nǒn yâa /
4 : ต่าบลปากแพรก / tam bon-pàak phrêæk /
5 : ตำบลบ้านเก่า / tam bon-bâan kàw /
$6:$ ต่าบลวังดัง / tam bon-wan dôy /
7 : ตำบลท่ามะขาม / tam bon-thâa ma khaam /
$8:$ ต่าบลลาดหญ้า / tam bon-lâat yâa /
9 : ดำบลช่องสะเดา / tam bon-chôn sa daw /
10 : ตำบลวังเย็น / tam bon-wan yen /
11 : ตำบลแก่งเสี้ยน / tam bon-kæ̂æy siân /

Finally, the name of the village / หมูบาน - mùu - bâan/ is put on the card:

For example, there are 8 villages in Nong bua sub-district of Muang district of Kanchaburi province:

$\begin{array}{ll}\text { บ้านห้วยหอยกาบ } & \text { / bâan-huây-hǒ̌y-kàap / } \\ \text { บ้านหนองบัว } & \text { / bâan-nǒn-bua / } \\ \text { บ้านหนองบัว } & \text { / bâan-nǒy-bua / } \\ \text { บ้านพุพระ } & \text { / bâan-phúi-phra / } \\ \text { บ้านพุเลียบ } & \text { / bâan-phú?-liâp / } \\ \text { บ้านป่านางเย้อ } & \text { / bâan-pàa-naay-yá / }\end{array}$




\begin{tabular}{|c|c|c|}
\hline \multirow{2}{*}{$\begin{array}{c}\text { บ้านพุประด่ } \\
\text { บ้านตลิ่งแดง } \\
\text { Sample cards }\end{array}$} & \multicolumn{2}{|c|}{$\begin{array}{l}\text { / bâan-phú?-pra-dùu / } \\
\text { / bâan -ta lî n-dææ̣ / }\end{array}$} \\
\hline & ห้วยหอยกาบ & กจ - ก -1 \\
\hline
\end{tabular}

This card stands for the village name บ้านห้วยหอยกาบ / bâan-huây-hววัykàap /, Nong Bua sub-district, Muang district of Kanchanaburi, Kanchanaburi province.

พุประดู่ $\quad$ กจ - ก -1

This card stands for the village name บ้านพุประดู่ / bâan-phú2-pra-dùu /, Nong bua sub-district, Muang district of Kanchanaburi, Kanchanaburi province. 


\section{Appendix II}

List of village names from other ethnic languages in Kanchanaburi province (their origins and meanings need further study). For the analysis of meaning, the study emphasizes the first noun after the word บ้าน / bâan 'village'/ as an initial morpheme of a village name.

$\begin{array}{lll}1 & \text { หม่องกระแทะ } & \text { mòn } \mathrm{kra} \text { thæ } \\ 2 & \text { องหลุ } & \text { ?ọ lù } \\ 3 & \text { องลิต } & \text { Pọ lít District }\end{array}$

4 บะลังกา $\mathrm{ba}$ lan $\mathrm{kaa}$

Lau khwan District

$\begin{array}{lll}5 & \text { นิเถะ } & \text { ni thè } \\ 6 & \text { วังกะ } & \text { way kà } \\ 7 & \text { เวียคาดี้ } & \text { wia khaa dî̀ } \\ 8 & \text { ซองกาเรีย } & \text { sọ kaa ria } \\ 9 & \text { จงอั่ว } & \text { con ใuà } \\ 10 & \text { เสน่ห์พ่อง } & \text { sa nee phôn } \\ 11 & \text { กองม่องทะ } & \text { kooท mồ tha } \\ 12 & \text { เกาะสะเดิ่ง } & \text { ko sa də̀y } \\ 13 & \text { ไล่โว่ } & \text { lây wò } \\ 14 & \text { ทิไล่ป้า } & \text { thi lây paâ } \\ 15 & \text { จะแก } & \text { ca kææ }\end{array}$

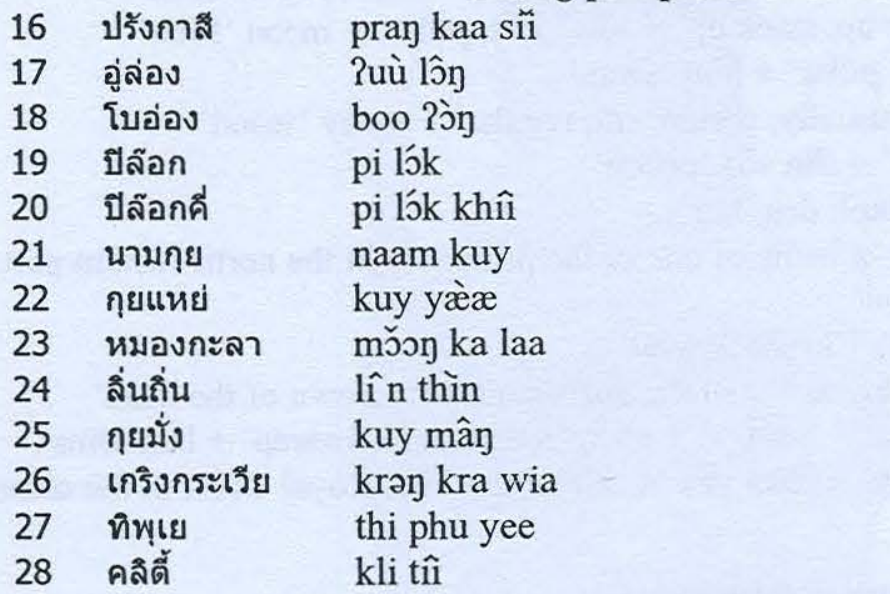

Thong pha phum District

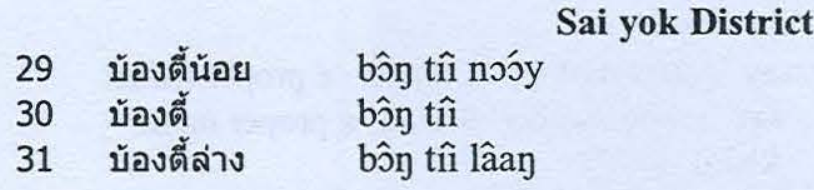




\section{Appendix III}

Village names of unclassifiable or unidentifiable or questionable (the numbers of names listed below is not equal to the total count of unclassified names in Table 1 because some of them are used more than once)

1. Unclassifiable group includes those names that the meanings are known but they cannot be put together with the other categories or that the meaning of each word is known but the whole meaning makes no sense in Thai. For the analysis of meaning, the study emphasizes the first noun after the word บ้าน /bâan 'village'/ as an initial morpheme of a village name.

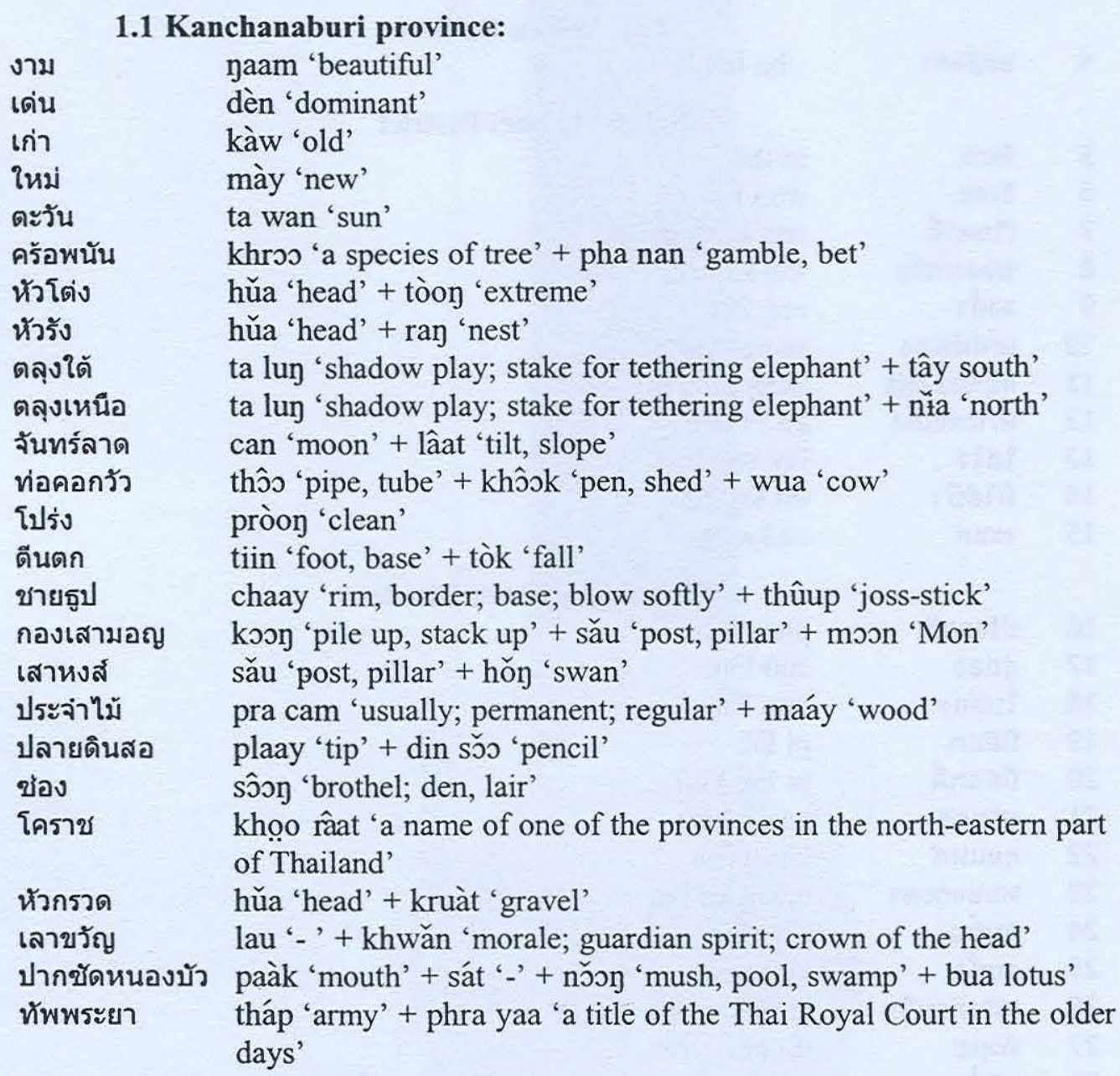

\subsection{Nakhon Pathom province:}

ทัพหลวง

ทัพยายท้าว

ทับยายเรือง

ถนนขาด

ตากแดด

หลักเมตร

ห่าง

วันครู

หอคอย tháp 'army' + lǔan 'royal'

tháp 'army' + yaay 'grand-mother' + thaáw 'a proper name'

tháp 'house' + yaay 'grand-mother' + rian 'a proper name'

tha norn 'road' + khàat 'torn'

tàak 'expose, dry in the sun' + dæ̀ 'sun-light'

làk 'pole' + méet 'metre'

hàan 'far'

wan 'day' + khruu 'teacher'

hว̌ 'tower' + khəoy 'wait' 


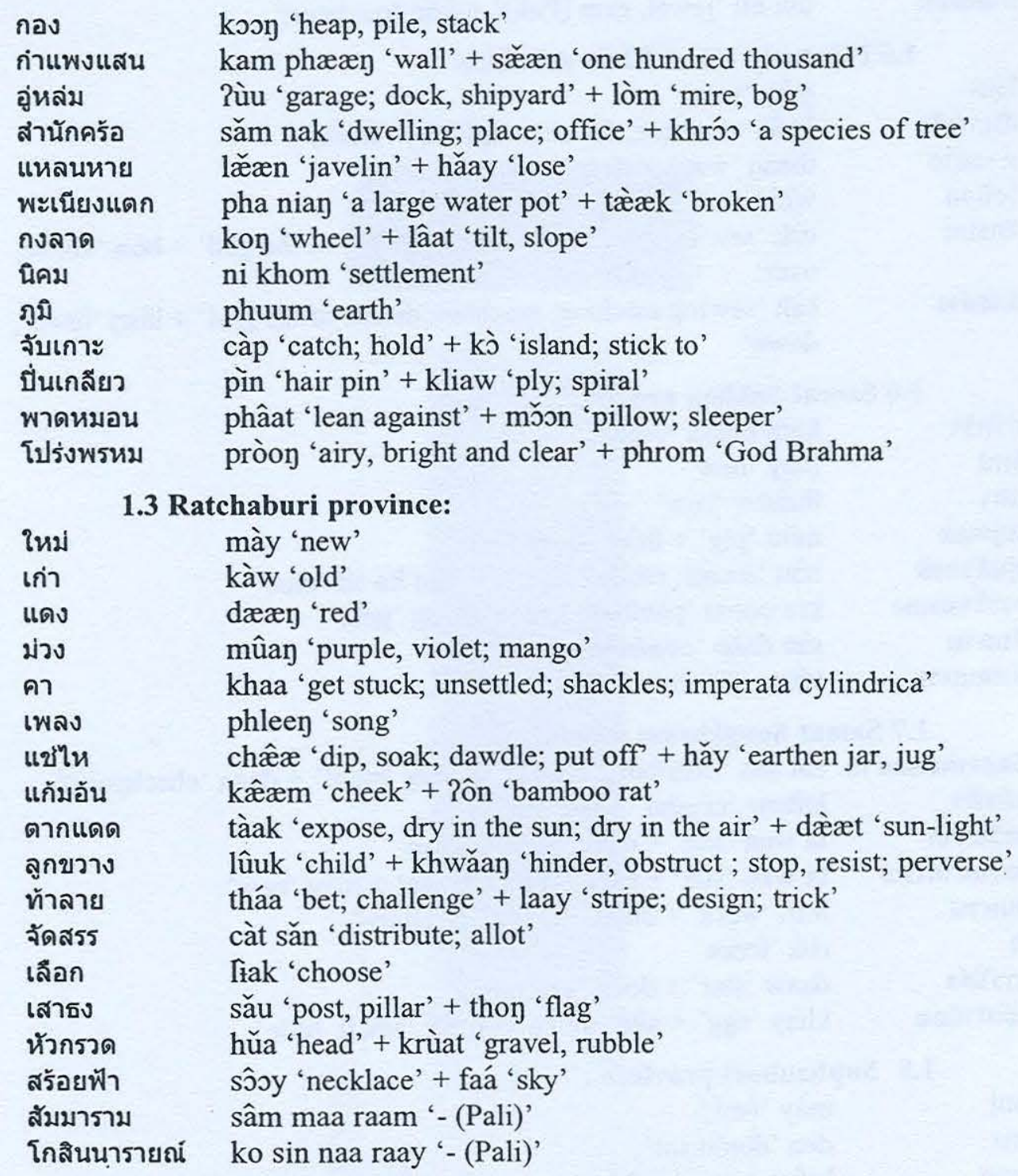

\subsection{Ratchaburi province:}

ใหม่

เก่า

แดง

ม่วง

คา

เพลง

แช้ไห

แก้มอ้น

ตากแดด

ลูกขวาง

ท้าลาย

จัดสรร

เลือก

เสาธง

หัวกรวด

สร้อยฟ้า

สัมมาราม

โกสินนารายณ์

mày 'new'

kàw 'old'

dææy 'red'

mûay 'purple, violet; mango'

khaa 'get stuck; unsettled; shackles; imperata cylindrica' phleen 'song'

chæ̂æ 'dip, soak; dawdle; put off' + hăy 'earthen jar, jug'

kæ̂æm 'cheek' + ?ôn 'bamboo rat'

tàak 'expose, dry in the sun; dry in the air' + dæ̀ 'sun-light'

lûuk 'child' + khwǎan 'hinder, obstruct ; stop, resist; perverse'

tháa 'bet; challenge' + laay 'stripe; design; trick'

càt săn 'distribute; allot'

Trak 'choose'

său 'post, pillar' + thoy 'flag'

hǔa 'head' + krùat 'gravel, rubble'

sôoy 'necklace' + faá 'sky'

sâm maa raam '- (Pali)'

ko sin naa raay '- (Pali)'

\subsection{Phetchaburi province:}

ใหม่

ม่วง

คำ

กรวย

ลิ้นช้าง

พี่เลี้ยง

ปากง่าม

ถม

เพรียง

พะเนิน

ลำพัง

ไล่เบี้ย

เพชรบูรณ์ mày 'new'

mûan 'purple, violet; mango'

kham 'word; gold'

kruay 'funnel; cone'

1 'in 'tongue' + cháan 'elephant'

phîi 'elder brother or sister' + lián 'raise'

pàak 'mouth' + nâam 'fork, prong'

thǒm 'fill, cover; much, many; inscribe with sacred letters'

phrian 'shipworm, barnacles; do something in unison, as in phrósm phrian'

pha nəən 'large hammer; piled up as in pha nəən thəən thí $\mathrm{k}$ '

lam phan 'only; alone'

lây bîa 'find out; investigate'

phet cha buun 'a name of one of the provinces in the northern part of Thailand' 
มณีเลื่อน ma nii 'jewel, gem (Pali)' + Tran 'postpone'

\begin{tabular}{|c|c|}
\hline ใหม่ & mày 'new' \\
\hline คั่นกระได & khân 'separate, divide' + kra day 'ladder' \\
\hline ทางสาย & thaan 'way' + săay 'line, route' \\
\hline วิ่งน้อย & wîn 'run’ + nó́y 'small, little' \\
\hline จักรบน & $\begin{array}{l}\text { càk 'sewing machine; machine; discus of the god' }+ \text { bon 'above, } \\
\text { over' }\end{array}$ \\
\hline จักรล่าง & $\begin{array}{l}\text { càk 'sewing machine; machine; discus of the god' + lâan 'lower, } \\
\text { down' }\end{array}$ \\
\hline
\end{tabular}

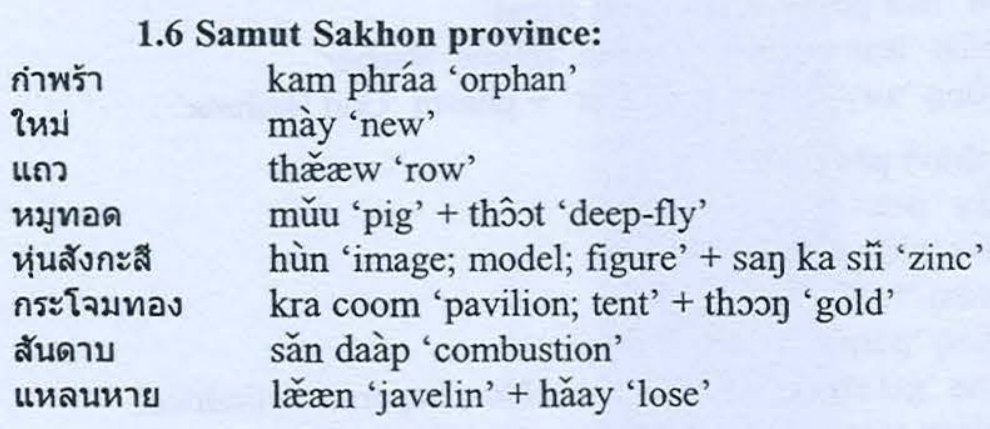

1.7 Samut Songkhram province:
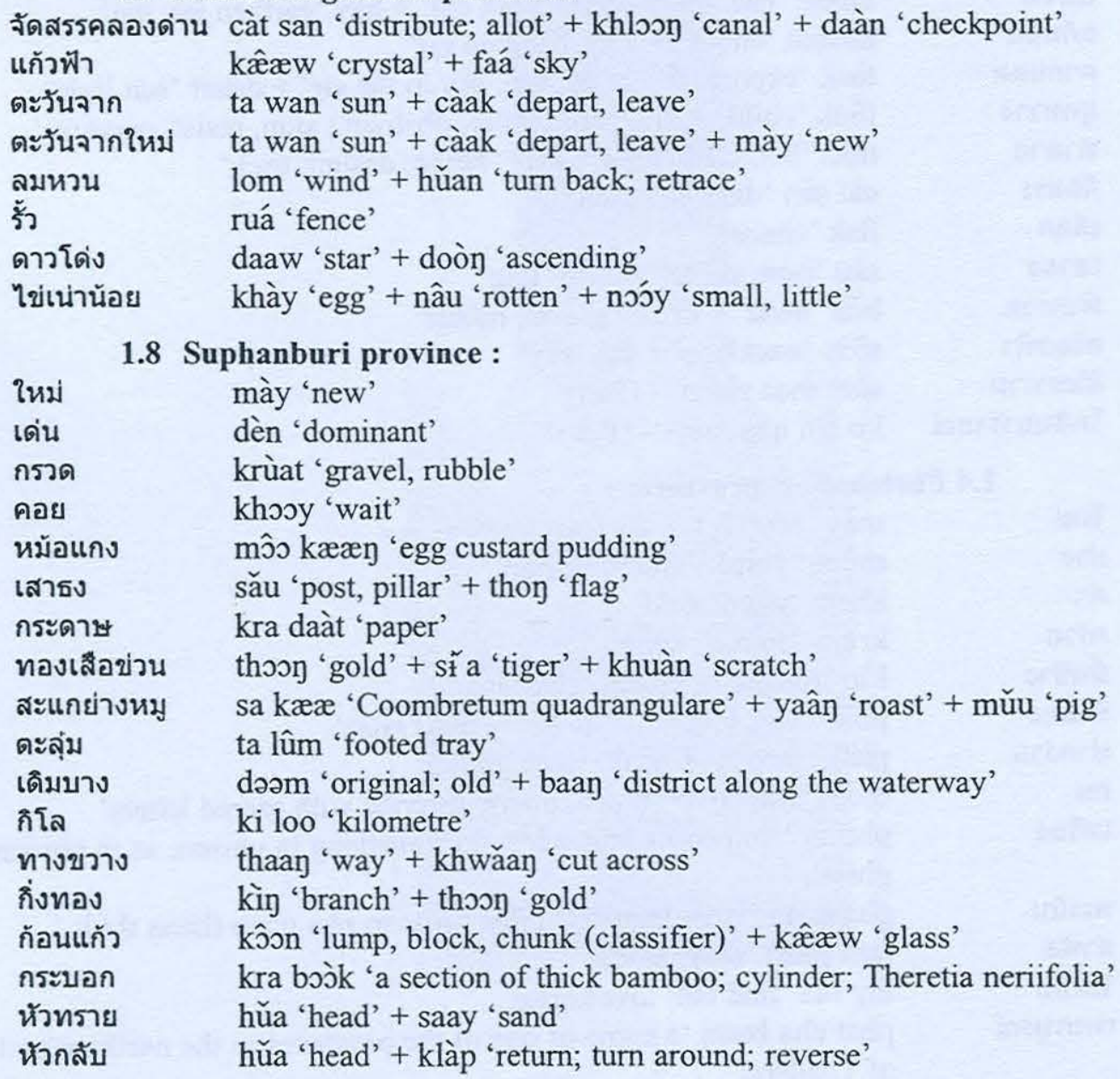


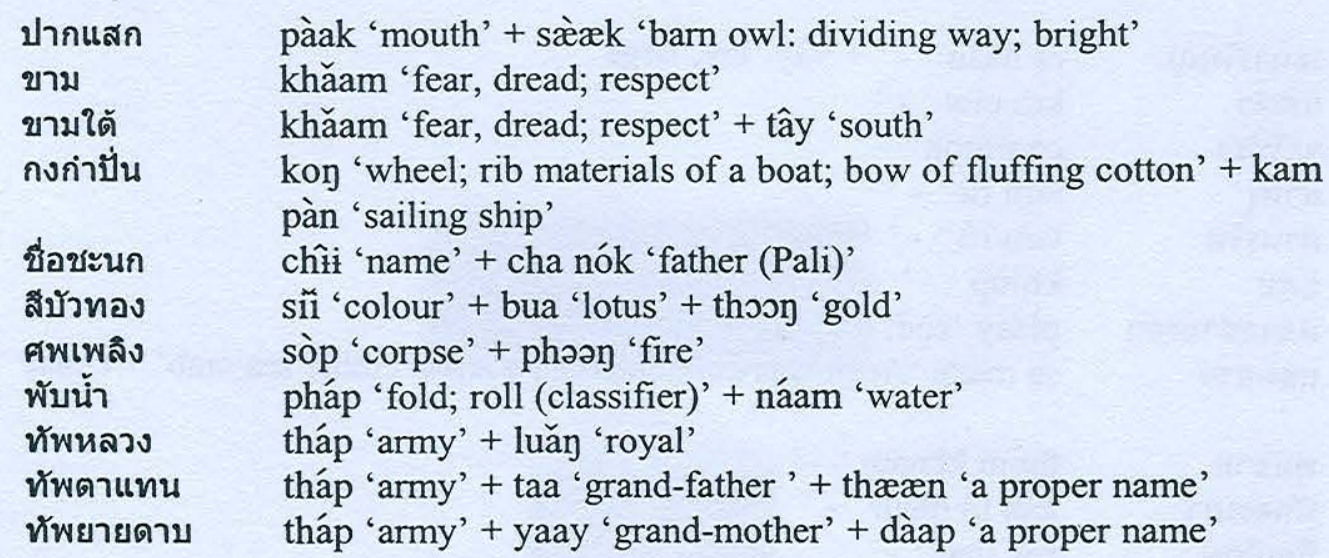

2. Unidentifiable or questionable group includes those names that their meanings or parts of their meaning are unknown. For the analysis of meaning, the study emphasizes the first noun after the word บ้าน / bâan 'village'/ as an initial morpheme of a village name.

\subsection{Kanchanaburi province:}

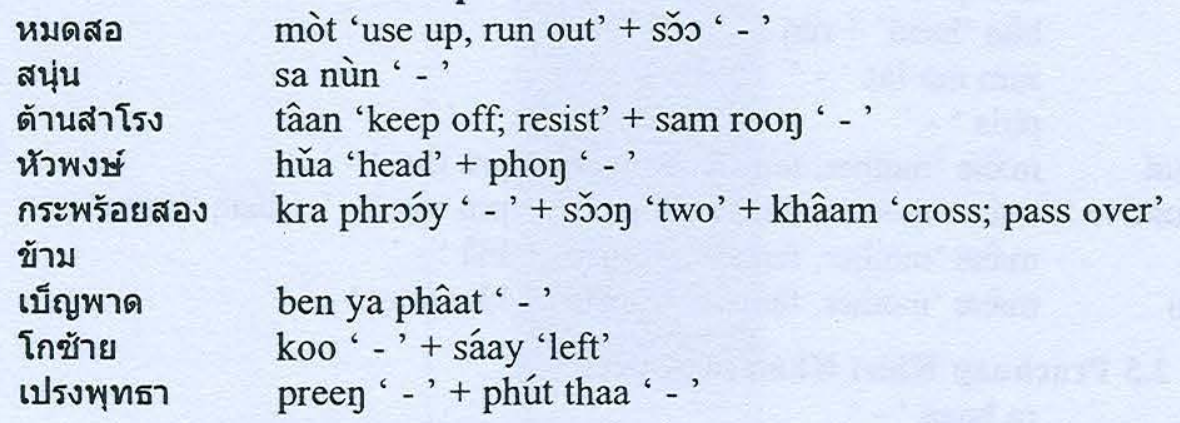

\subsection{Nakhon Pathom province:}

ปี่งเกลียว pìn ' - ' + kliaw 'ply; spiral'

โกสำนัก $\mathrm{koo}$ ' - ' + săm nák 'dwelling; place; office'

กระดีเดียว $\quad \mathrm{kra}$ dii ' - ' + diaw 'single, sole; same, identical'

ราดสระแก râat 'sprinkle, pour' + sa 'pond' + kææ ' - '

ทรงคนอง son kha noวn " - '

สัมปทวน sam pa thuan ' -'

วงพาท woy phâat ' -'

หลายวงพาท laay 'many, a lot' + woy phâat ' -'

กระดีบ

กระดื้ออ

kra tìip ' - '

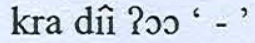

\subsection{Ratchaburi province:}

$\begin{array}{ll}\text { หัวสะนุ่น } & \text { hǔa 'head' + sa nùn ' -' } \\ \text { คีบอน } & \text { khii boon ' - } \\ \text { เจตั้ว } & \text { cee tûa ' -' } \\ \text { ซาปอกง } & \text { sam poo kon ' - }\end{array}$

\subsection{Phetchaburi province:}

ระหาญ ra hǎan ' -

ระหารน้อย ra hǎan ' - ' + n’́วy 'small, little' 


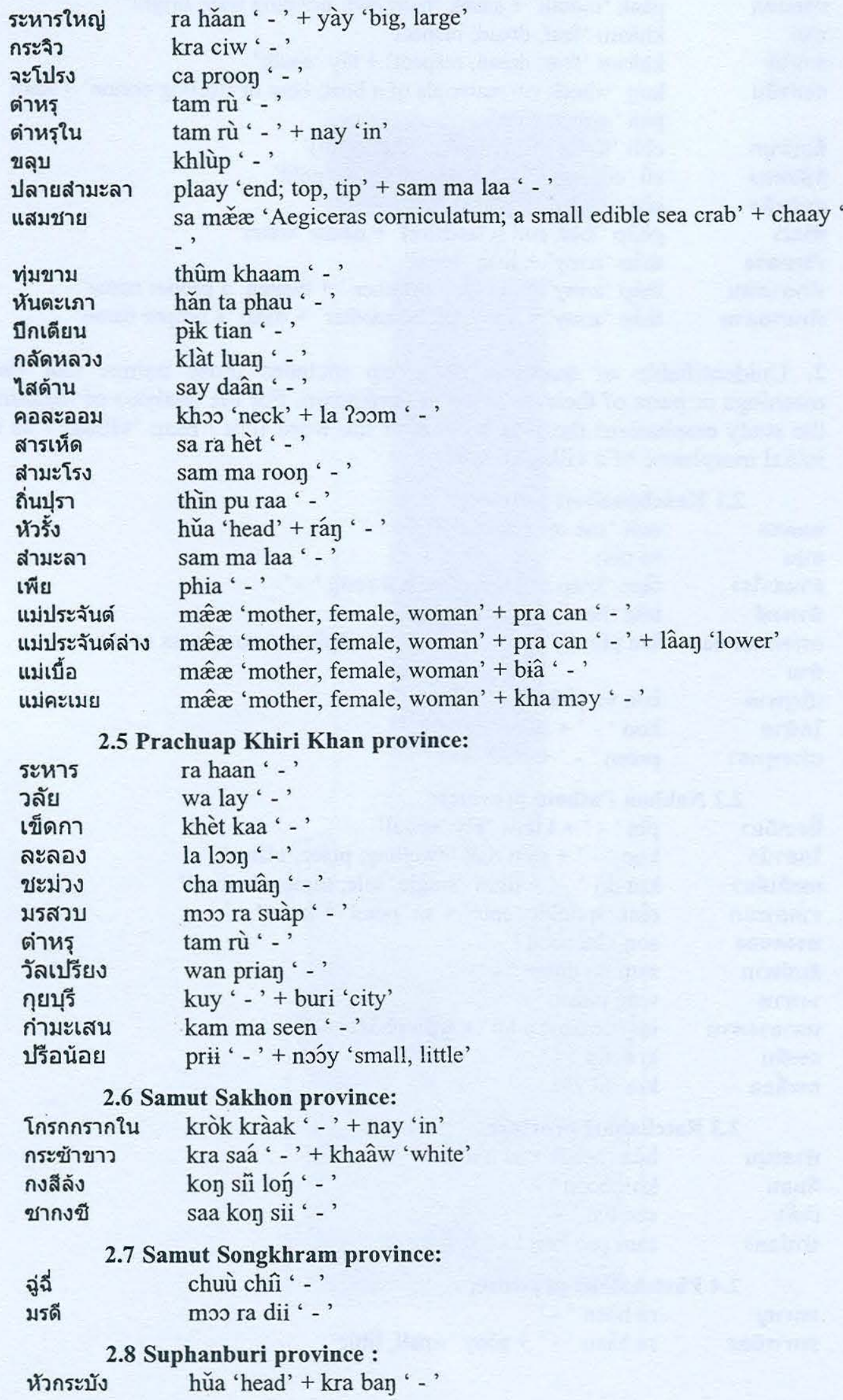

2.5 Prachuap Khiri Khan province:

ระหาร

วลัย

เข็ดกา

ละลอง

ชะม่วง

มรสวบ

ตำหรุ

วัลเปรียง

กุยบุรี

ก่ามะเสน

ra haan ' -'

wa lay ' - '

khèt kaa ' - '

la loon ' -'

cha muây ' - '

moo ra suàp ' -'

tam rù ' - '

wan prian ' -'

kuy ' - ' + buri 'city'

kam ma seen ' -'

ปรือน้อย

prii ' - ' + nó́y 'small, little'

2.6 Samut Sakhon province:

โกรกกรากใน kròk kràak ' - ' + nay 'in'

กระซ้าขาว kra saá ' - ' + khaâw 'white'

กงสีล้ง kon sĩ lón ' - '

ซากงซี saa kon sii ' -

2.7 Samut Songkhram
ฉูนิ
มรดี
chuù chî̀ ' -
moว ra dii ' -

2.8 Suphanburi province :

หัวกระบัง hǔa 'head' + kra bay ' - ' 


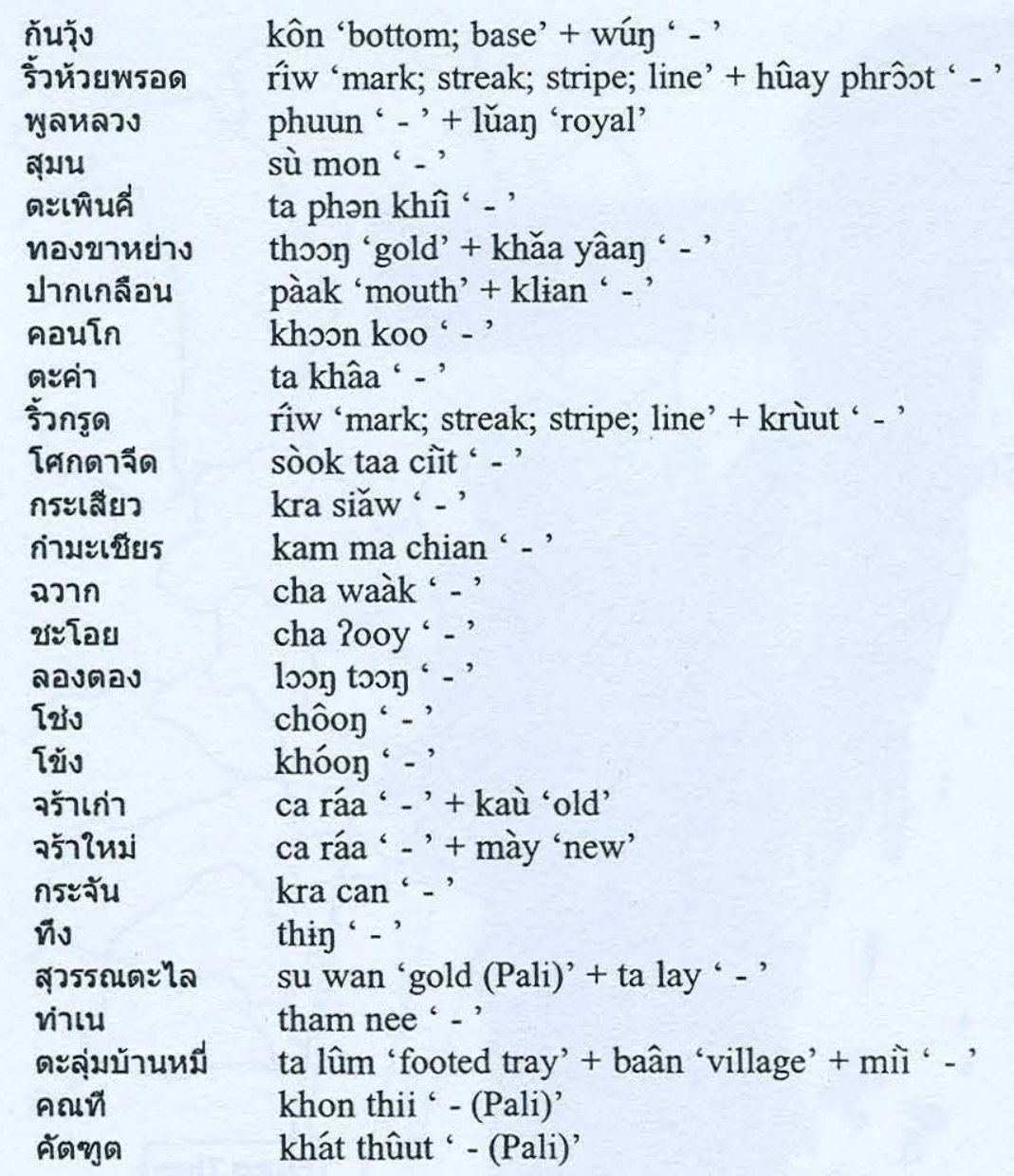




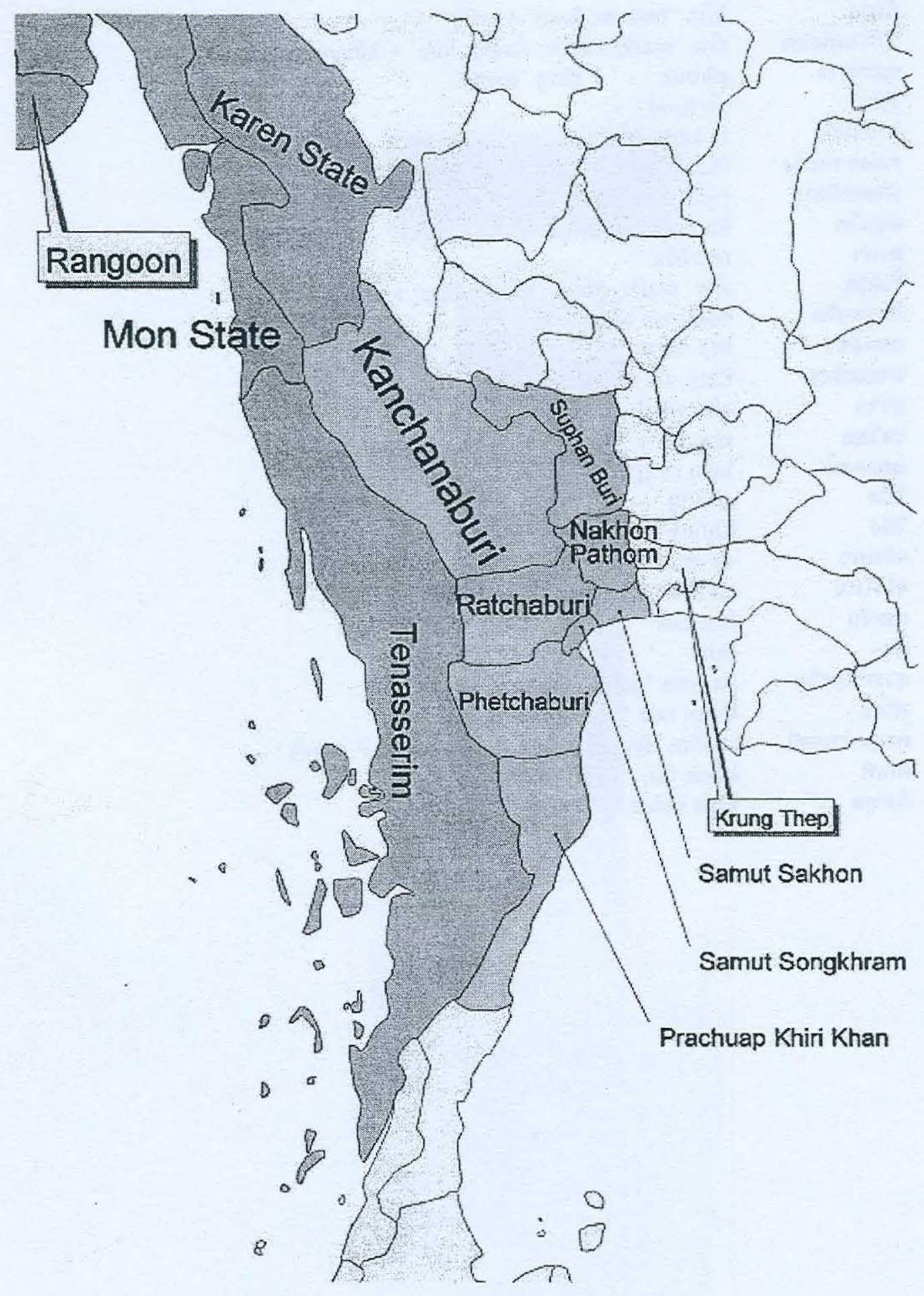

Map 1: The eight provinces in the western region 


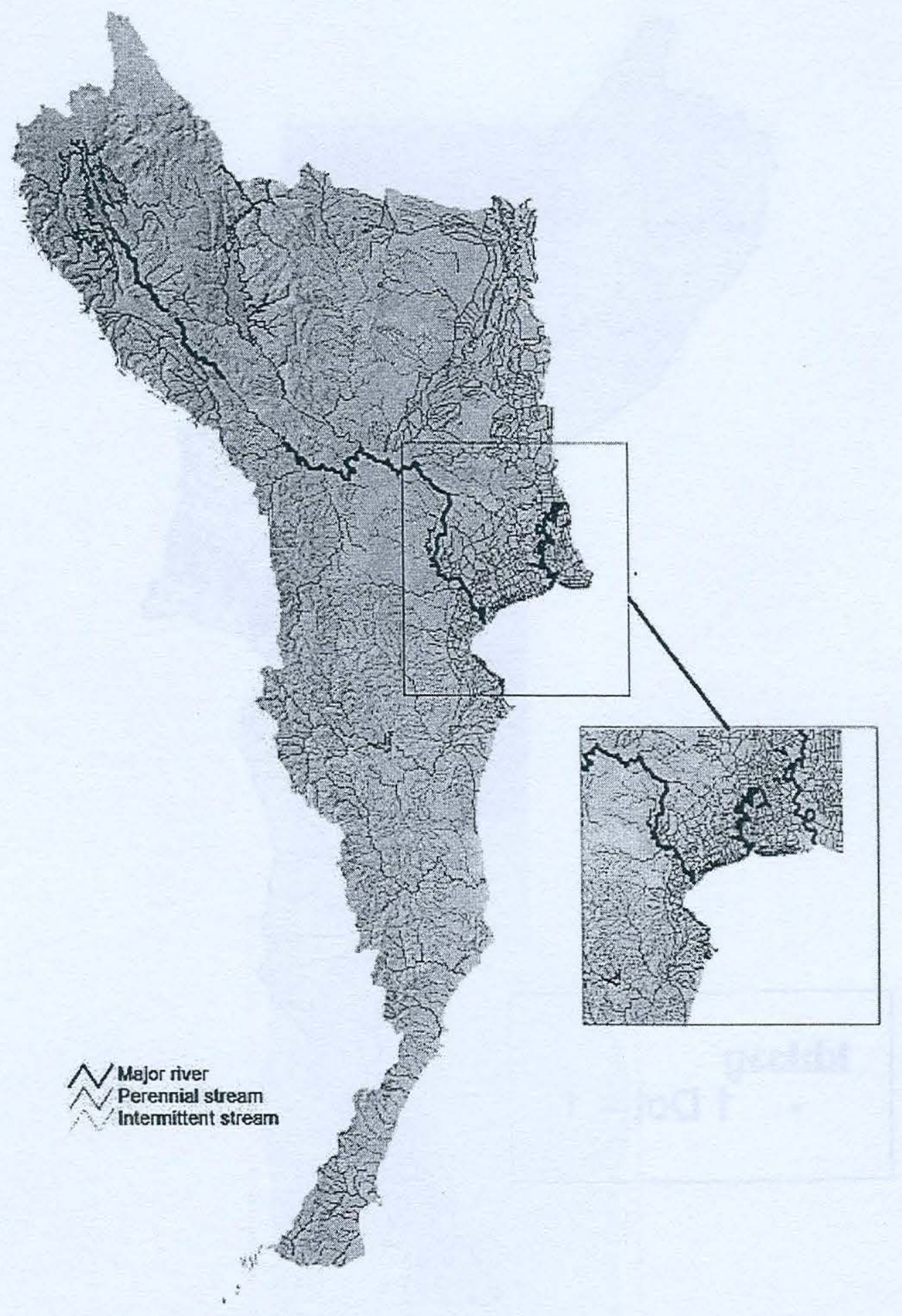

Map 2: Geographical map of the eight provinces

(the density of water ways in the region) 


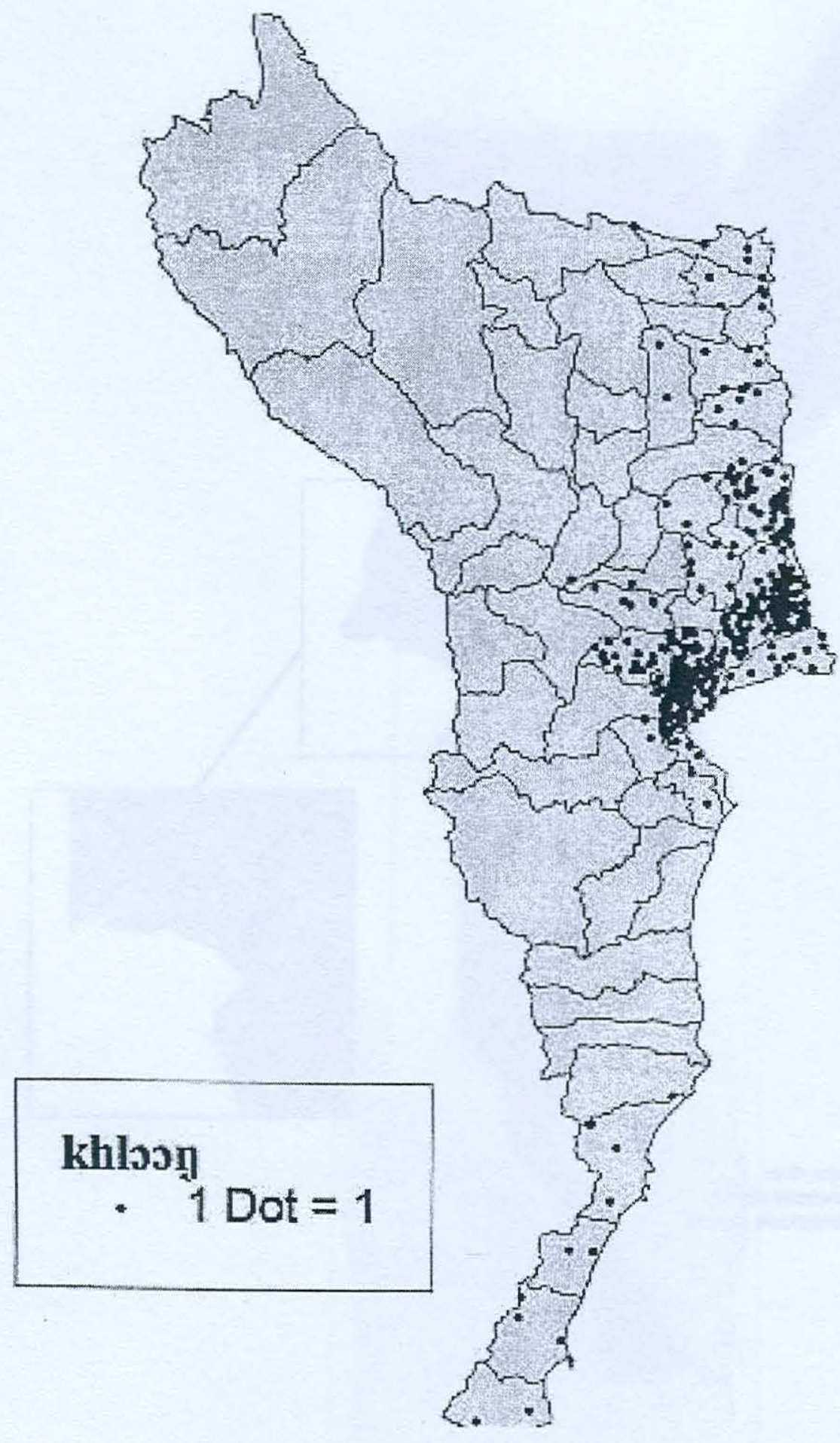

Map 3: Occurrences of the generic noun khloon 


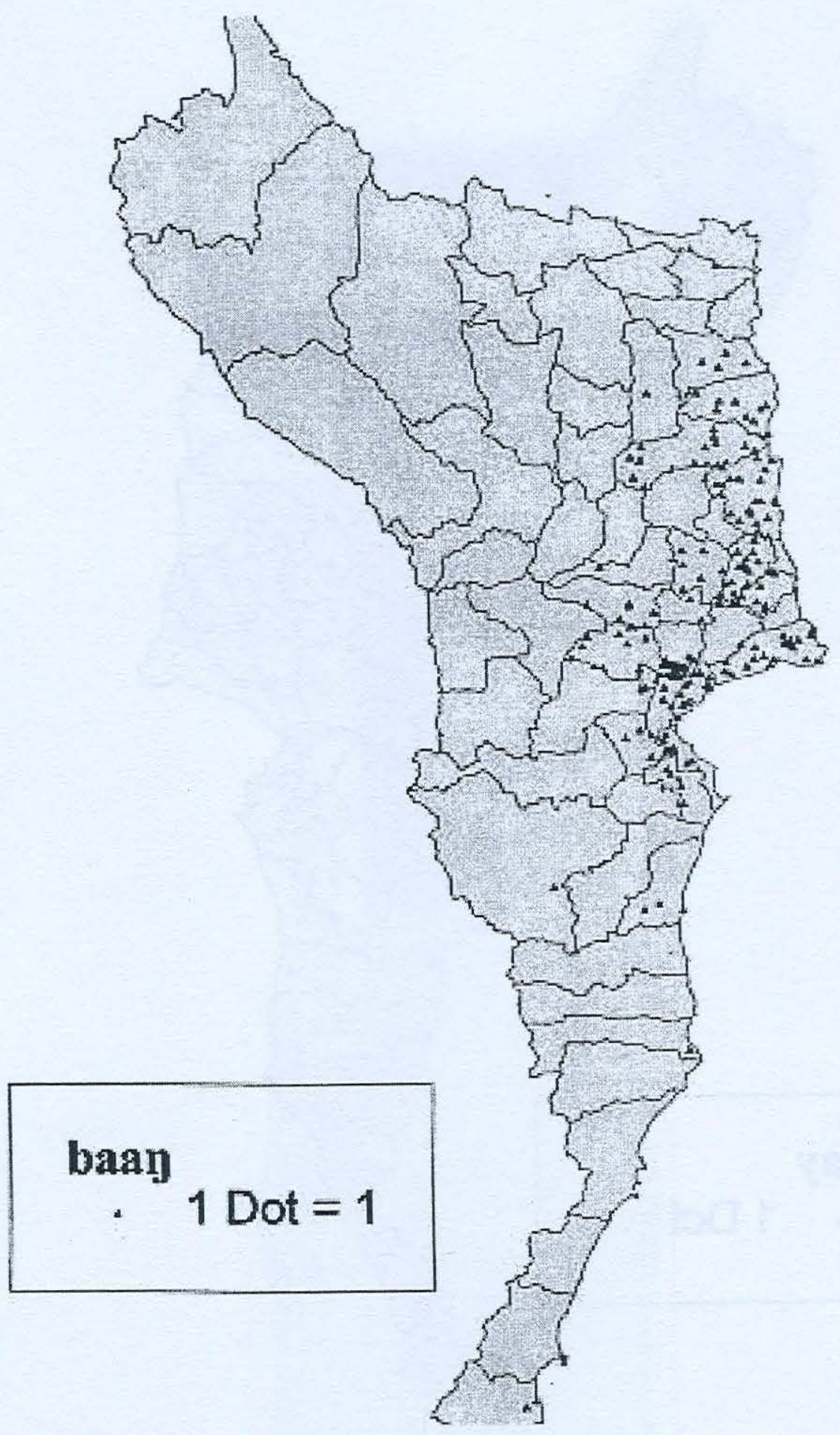

Map 4: Occurrences of the generic noun baan 


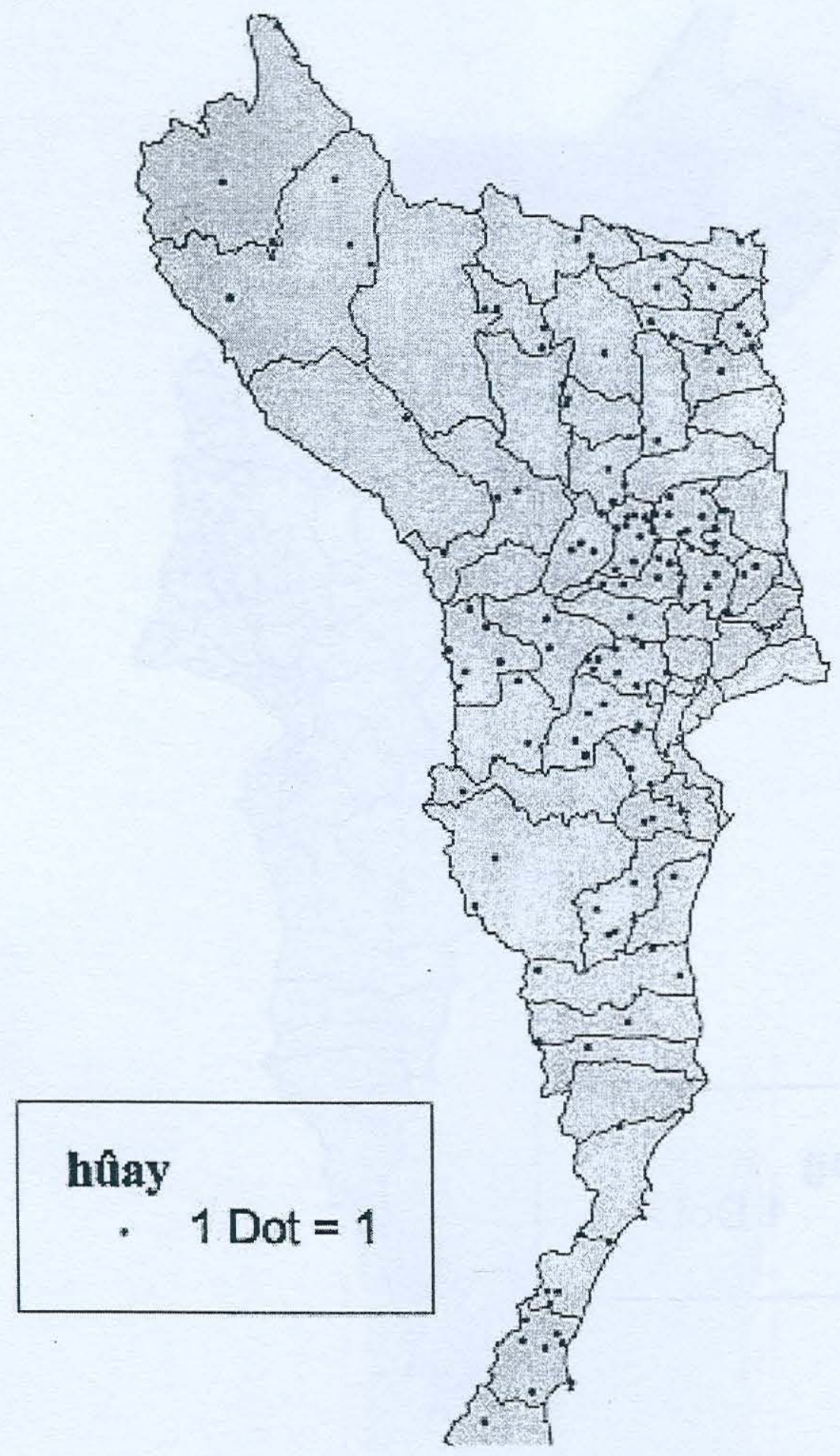

Map 5: Occurrences of the generic noun hûay 


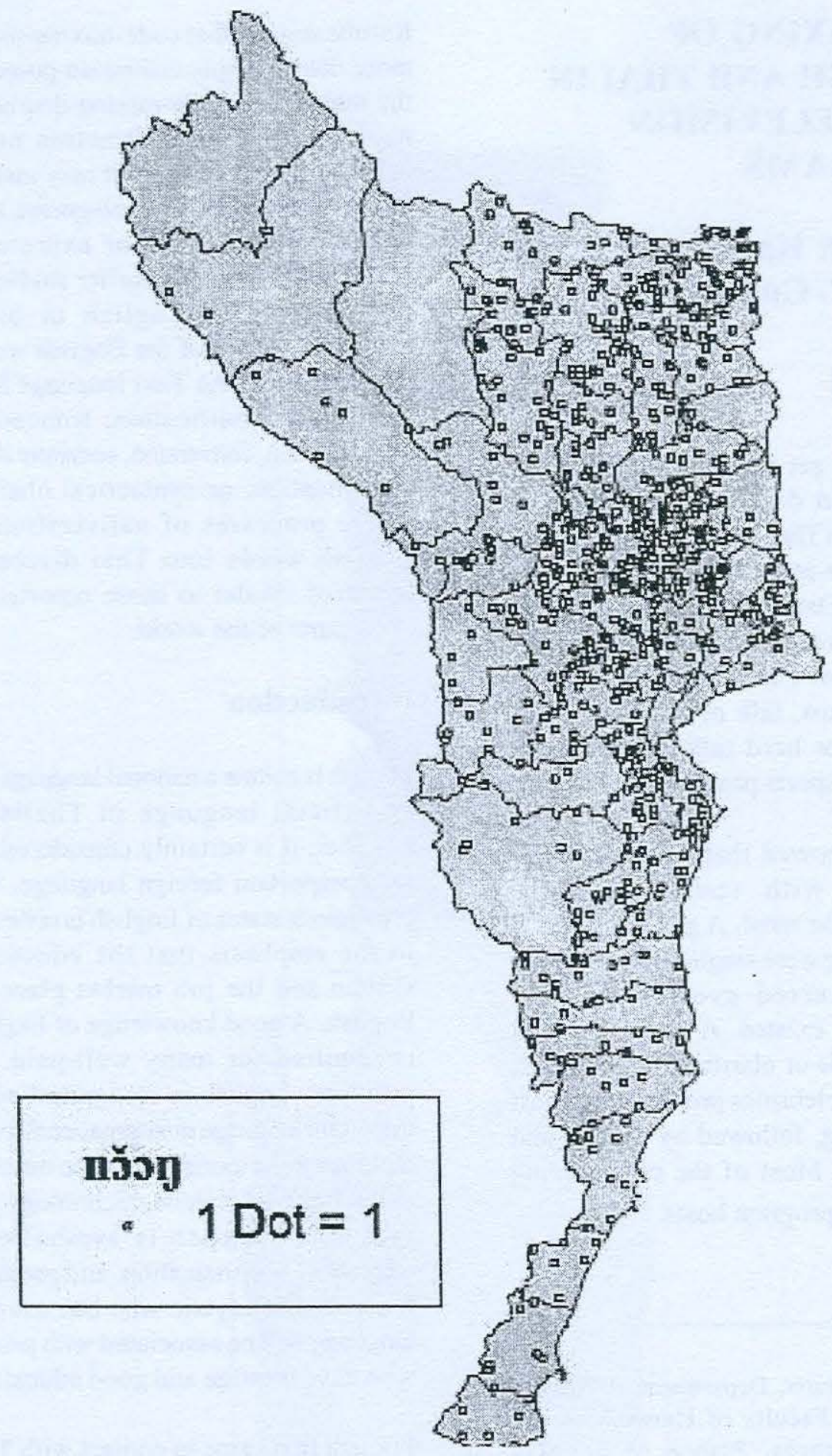

Map 6: Occurrences of the generic noร̌n 